\title{
Embryonic expression pattern of a family of Drosophila proteins that interact with a central nervous system regulatory element
}

\author{
Sarah J. Bray, ${ }^{1}$ Brian Burke, ${ }^{2}$ Nicholas H. Brown, ${ }^{3}$ and Jay Hirsh ${ }^{1}$ \\ 'Department of Biological Chemistry and Molecular Pharmacology, ${ }^{2}$ Department of Molecular and Cellular Physiology, \\ Harvard Medical School, Boston, Massachusetts 02115 USA; $^{3}$ Department of Cell and Developmental Biology, The Biological \\ Laboratories, Harvard University, Cambridge, Massachusetts 02138 USA
}

The protein Elf-1 interacts with a cis-acting element that is required specifically for the neuronal expression of the Drosophila dopa decarboxylase gene Ddc. Using protein purified from Drosophila embryos, we raised Elf-1-specific monoclonal antibodies. The expression of Elf-1 during embryogenesis is restricted to nuclei of tissues derived from ectoderm, predominantly the central nervous system (CNS) and the epidermis. Within the CNS, Elf-1 is present in only a small fraction of nuclei, and the pattern of expressing nuclei changes dramatically during development. Elf-1 and $D d c$ are coexpressed in primary cultures of neural cells. However, we do not detect Elf-1 in Ddc-expressing neurons in vivo, leading to the suggestion that Elf-1 activity is required in vivo for initiation of $D d c$ expression but not for its maintenance. The antibodies also were used to isolate cDNA clones encoding Elf-1. Alternate forms of Elf-1 mRNA result in at least three protein isoforms.

[Key Words: CNS; Elf-1; Ddc gene expression; DNA-binding proteins]

Received April 14, 1989; revised version accepted June 1, 1989.

One fundamental mechanism involved in differentiation is the programming of specific spatial patterns of gene expression. It appears that the enhancers or promoters that confer these specific patterns consist of multiple sites that are recognized by specific DNAbinding proteins (e.g., Maniatis et al. 1987). The interactions between DNA-binding proteins that are active in different but overlapping subsets of cells or tissues thus will determine the pattern of expression of a gene. Many of the proteins required for the early stages of embryonic development in Drosophila appear to be transcription factors (Desplan et al. 1988; Ingham 1988; Han et al. 1989) and are expressed in overlapping domains, which is consistent with this model. However, genetic studies in Drosophila indicate that some of the proteins required to initiate a pattern of expression may be different from those required to modify or to maintain expression at later stages during development (e.g., Struhl and Akam 1985; Duncan 1986; see also Scott and Carroll 1987). Trans-acting factors that play this type of transient role in the developmental expression of a gene may not be detected using in vitro or cell culture systems to assay gene expression. However, the ability to integrate genes into the germ line of Drosophila using P-element vectors (Rubin and Spradling 1982) allows for the detection of all the regulatory systems that affect expression of a gene. Using this approach, the cis-acting sequences required for the cell-specific expression of the Drosophila dopa decarboxylase gene $(D d c)$ in the central nervous system (CNS) have been analyzed (Scholnick et al. 1986; Beall and Hirsh 1987; Bray et al. 1988; Johnson et al. 1989). One of these sequence elements binds a factor that appears to play a transient role in regulating this expression, as indicated by the results in this paper.

$D d c$ is expressed in both the CNS, where the enzyme catalyzes the final step in the synthesis of serotonin and dopamine (Livingstone and Tempel 1983), and the epidermis, where it is required for cuticle hardening (Wright et al. 1976). Within the CNS, Ddc expression commences during late embryogenesis in $\sim 150$ neurons, and the expression continues throughout the remainder of larval development (Beall and Hirsh 1987; Konrad and Marsh 1987; Valles and White 1988). Most, if not all, of these $D d c$-expressing neurons also survive metamorphosis and persist through adult development (Budnik and White 1988; Valles and White 1988). The regulation of this $D d c$ expression in the CNS involves the combined effect of multiple regulatory elements: one a 16-bp sequence, element I, located at -60 relative to the transcription start site, and others contained within a distal enhancer between -1623 and -1019 (Scholnick et al. 1986; Beall and Hirsh 1987; Bray et al. 1988; Johnson et al. 1989). Some of the cis-acting elements within this distal enhancer regulate $D d c$ expression in defined 
subsets of neurons (Johnson et al. 1989), whereas wildtype element I function is required for $D d c$ expression in all neurons (Bray et al. 1988). Point mutations in element I essentially abolish neuronal expression of $D d c$. A nuclear protein, now referred to as Elf-l (for element Ibinding activity), interacts with element I and has reduced affinity for these functionally inactive mutated element I sites. The correlation between the in vivo expression of $D d c$ and the in vitro binding of Elf-1 leads us to conclude that this protein is involved in the regulation of neuronal expression of Ddc. Also, this protein interacts with sequences adjacent to other transcription units, including Ultrabithorax (Biggin and Tjian 1988) and engrailed (Soeller et al. 1988; S.J. Bray, unpubl.), although there is currently no evidence that these binding sites are required for correct expression of the genes in vivo. Now we have purified Elf- 1 and generated specific monoclonal antibodies. These antibodies have enabled us both to examine the spatial expression of Elf-l in embryos and to obtain cDNA clones encoding the protein.

\section{Results}

\section{Elf-1-specific monoclonal antibodies}

Elf-1 was purified from nuclear extracts prepared from 10- to 22-hr Drosophila embryos by sequential column chromatography using heparin-agarose, nonspecific DNA cellulose, and an element I oligonucleotide affinity resin (see Materials and methods). As a final step in the purification, the Elf-1 activity eluted from the oligonucleotide column was fractionated on an FPLC Mono Q anion exchange column. At all stages in the purification, Elf- 1 activity was assayed by its ability to protect element I from DNase I digestion. The element I-binding activity eluted from the Mono Q column in three fractions that contained four to five proteins when analyzed on a silver-stained SDS-polyacrylamide gel (Fig. 1B). These proteins, which migrate with apparent molecular masses between $\sim 60$ and $120 \mathrm{kD}$, coelute with Elf- 1 on other columns (data not shown); and, as described later, these polypeptides share common epitopes.

This highly purified material was used to raise Elf-1specific monoclonal antibodies (mAbs), which were identified using an adaptation of a gel electrophoresis DNA-binding assay. Antibodies that interact with Elf- 1 form a mAb-Elf-1-DNA complex, which migrates more slowly in the gel than the Elf-1-DNA complex alone does. We screened $\sim 200$ clones and identified two monoclonal antibodies that recognized Elf-1. (Fig. 2A). The complex containing mAb BF1 migrates more slowly than that containing mAb AE9, indicating that the two antibodies are different. Because both antibodies belong to the IgG class (data not shown), the difference in mobility is not the result of the antibody molecular weight and presumably results from the specific conformation of each mAb-Elf-1-DNA complex.

To confirm that monoclonal antibodies AE9 and BF1 recognize Elf-1 activity, we demonstrated that the pro- teins immunoprecipitated by both antibodies have specific Elf-1. The monoclonal antibodies were bound to anti-mouse Sepharose, and the washed resin was incubated with crude embryonic nuclear extract. After incubation, the supernatant was assayed by DNase I protection and found to be depleted fully of Elf-1 activity (Fig. 2B). In addition to demonstrating further the interaction of the monoclonal antibodies with Elf- 1 , this indicates that the crude nuclear extract does not contain detectable amounts of another immunologically unrelated Elf-1. The immunoprecipitated protein then was assayed directly for Elf-1. The protein bound to the Sepharose beads was incubated with a mixture of two labeled oligonucleotides: element I, which contained an Elf-1binding site, and element II, which did not. Oligonucleotides binding to protein on the resin were eluted with high salt and analyzed on a polyacrylamide gel (Fig. 2C). Protein immunoprecipitated by mAbs AE9 and BF1 specifically binds the element I oligonucleotide. The incubations also were carried out in the presence of 50-fold excess of unlabeled element I or element II oligonucleotides to show that only the specific element I oligonucleotide was able to compete.

We compared the polypeptides recognized by $\mathrm{mAb}$ BF1 with those present in the most highly purified preparations of Elf- 1 . In a crude fraction from the DNA cellulose column, mAb BF1 recognized polypeptides (Fig. $1 C)$ whose molecular weights appear indistinguishable from those observed in the most purified Elf-1 fractions (Fig. 1B). We found also that both monoclonal antibodies immunoprecipitate all the polypeptides in the purified Elf-1 preparation (data not shown). These data indicate that most, if not all, of the proteins in the active fractions eluted from the Mono $Q$ column share common epitopes and that the antibodies cross-react with only this small number of polypeptides.

\section{Isolation of cDNA clones encoding Elf-1: alternate $m R N A$ s give rise to multiple Elf-1 isoforms}

The mAb BFl was used to isolate cDNA clones that expressed the Elf-1 epitope from an embryonic $\lambda g t 11$ expression library. Two cDNA clones, each $\sim 1 \mathrm{~kb}$ in length, were detected in the primary screen and rescreened with both mAbs BFl and AE9. Only one of the cDNAs produced a protein that also was recognized by mAb AE9, demonstrating that the two cDNAs were independent clones. Then we used these two clones as hybridization probes to isolate plasmid clones from an 8- to 12-hr embryonic cDNA library (Brown and Kafatos 1988). Fifteen different cDNA clones, which hybridized to both $\lambda$ clones, were characterized. These clones were ordered by increasing size, on the basis of an estimate from supercoiled DNA, and designated A-O. Because the cDNA clones are inserted unidirectionally in a plasmid vector containing the SP6 RNA polymerase promoter, we were able to analyze the encoded protein by transcribing and translating the cDNA clones in vitro (Fig. 3A). The largest polypeptide encoded by each clone 
Bray et al.

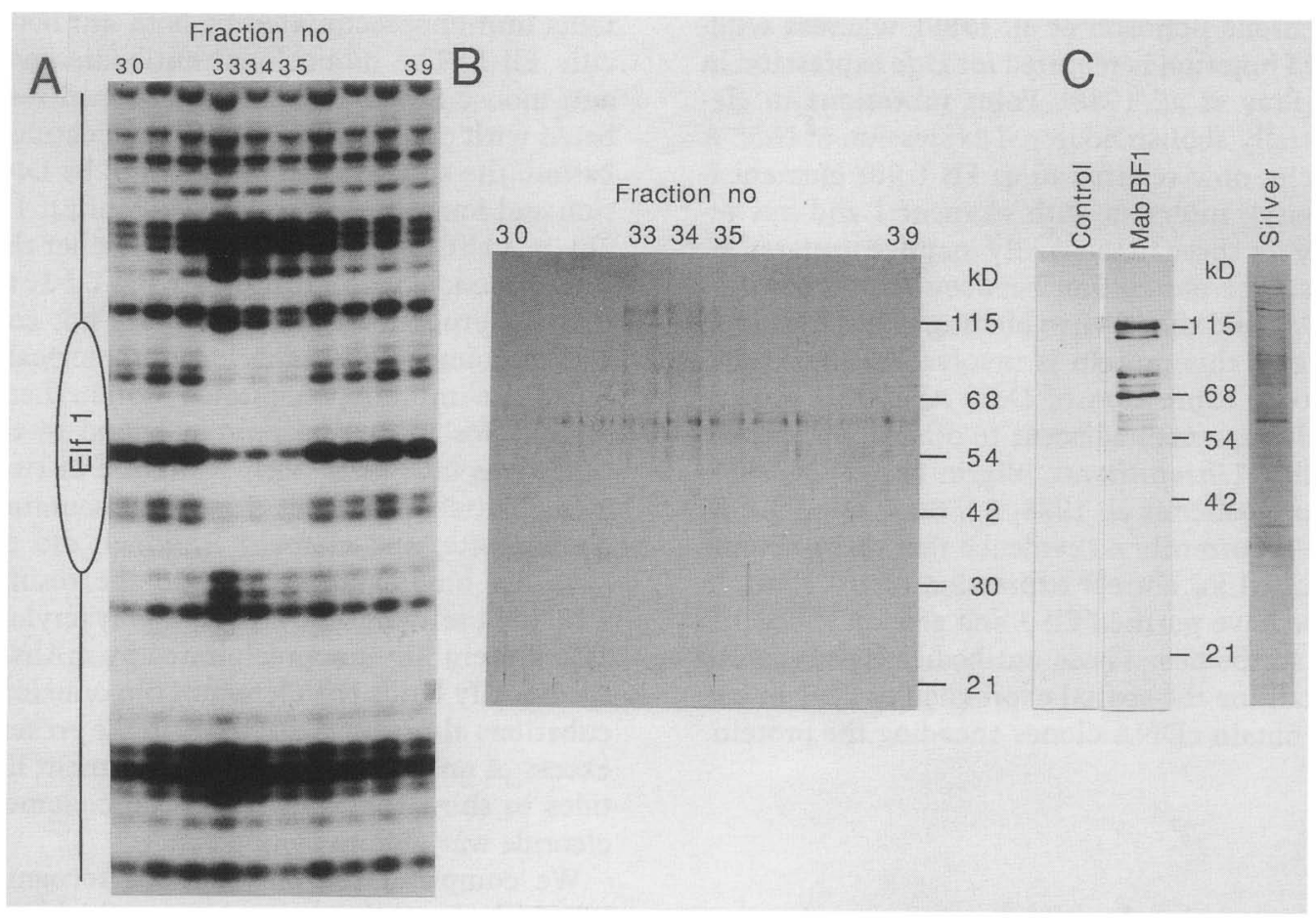

Figure 1. Purified Elf-1. The final step in the purification of Elf-1 activity was a Mono $Q$ anion exchange column. $|A|$ The fractions eluting from the column with increasing $\mathrm{KCl}$ between 0.15 and $0.3 \mathrm{M}$ were assayed for DNA-binding activity using a DNase I protection assay. Aliquots of each fraction were assayed for their ability to protect element I contained within a 188 -bp fragment from the $D d c$ promoter. Elf-1 activity was detected in fractions 33-35 eluting between 0.2 and $0.25 \mathrm{M} \mathrm{KCl}$. $(B)$ Aliquots of the same fractions were analyzed for protein content on an SDS-polyacrylamide gel, which was silver stained. The $\sim 63-\mathrm{kD}$ band present in all lanes is the result of contamination from the reducing agent in the sample buffer. $(C)$ A more crude preparation of Elf- 1 , the fraction eluting from DNA cellulose (see Materials and methods), was analyzed by Western blot using mAb BF1 and a control anti-Golgi monoclonal antibody. The silver-stained gel shows that this fraction contains a high complexity of protein. The $\mathrm{mAb} B F 1$ only reacts with a small number of low abundance proteins that have the same molecular weights as the proteins detected in the Mono $Q$ purified protein. The same pattern is observed if $\mathrm{mAb}$ AE9 is used. The control anti-Golgi monoclonal antibody does not cross-react with any protein in the fraction.

is related to the length of the cDNA, except in the case of clone $M$, which presumably contains a frameshift mutation or is a copy of an incompletely spliced RNA.

There are a number of smaller polypeptide products in the in vitro translations that arise from premature termination during transcription or translation and/or from initiations at internal methionines. The pattern of these partial products varies between the different clones, allowing identification of different classes of cDNA. For example, D, E, F, I, L, and N clearly differ from the other cDNAs in the size of the prominent small partial products. The combined data from this analysis and from restriction enzyme mapping show that the cDNA clones isolated fall into three classes, and that $\mathrm{N}, \mathrm{K}$, and $\mathrm{O}$ encode the full-length proteins representative of each class (Fig. 3B). $\mathrm{N}$ and $\mathrm{K}$ class cDNAs differ in a small region close to the carboxy-terminal of the protein, whose maximum length is $500 \mathrm{bp}$. The $O$ class resembles the $\mathrm{K}$ class in this carboxy-region, but $\mathrm{O}$ differs extensively from both $\mathrm{N}$ and $\mathrm{K}$ classes in more $5^{\prime}$ regions. We do not know whether $O$ shares the same amino terminus with $\mathrm{N}$ and $\mathrm{K}$, and it is possible that the O mRNA is initiated from a different promoter. Both the monoclonal antibodies bind to all three protein isoforms (data not shown), but the differences between these three forms are not sufficient to account for all the polypeptide species detected in the purified Elf-1 fractions. Additional variation could result from other mRNA variants that we have not detected yet, or from posttranslational modifications or from proteolytic degradation of the full-length proteins.

To confirm that the isolated cDNA clones encode Elf-1, we have shown that their in vitro translation products protect element I from DNase I digestion. The longer cDNA clones were not transcribed and translated as efficiently as the smaller partial cDNA clones, presumably because of their large size. Thus, we found it easier to detect DNA binding with the products from the smaller clones. Figure 4 demonstrates that the product of cDNA $F$ is able to protect element I from DNase I digestion in the wild-type $D d c$ promoter and that the footprint is almost identical to the one produced by the protein in crude nuclear extract. Proteins encoded by all three cDNA classes bind to element I, giving similar patterns of protection (data not shown). The extent of the protection is the same for the in vitro-synthesized 

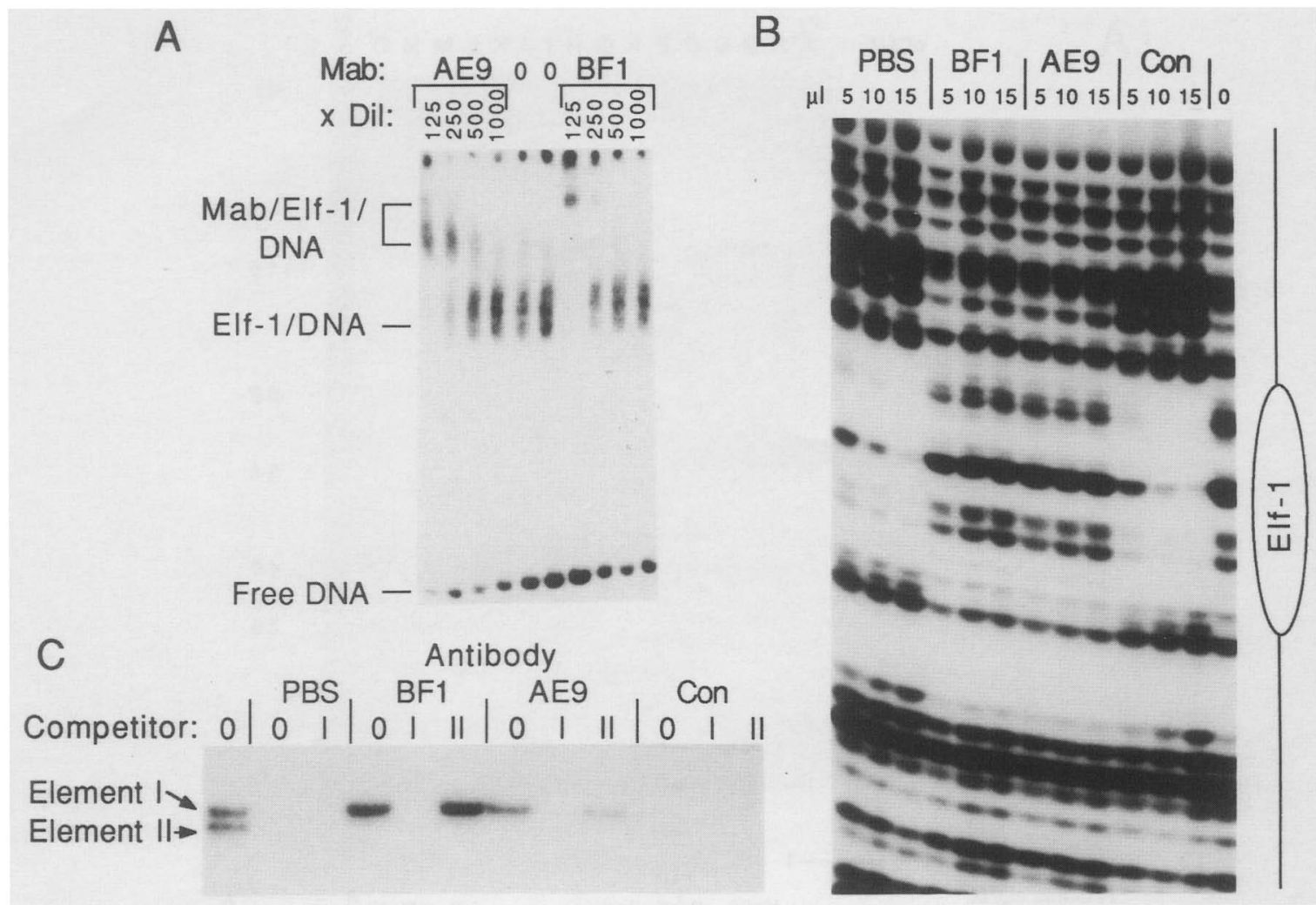

Figure 2. Monoclonal antibodies immunoprecipitate Elf-1 activity. (A) Two independent monoclonal antibodies, AE9 and BF1, recognize Elf-1. Monoclonal antibodies were preincubated with affinity-purified Elf- 1 before the addition of a ${ }^{32} \mathrm{P}-\mathrm{labeled}$ DNA fragment that contained the Elf- 1 binding site. In the absence of monoclonal antibodies $(0)$, the Elf- 1 binds to the DNA, forming a complex. In the presence of monoclonal antibodies that react with Elf-1 (AE9 and BF1), a mAb-Elf-1-DNA complex is formed, which migrates more slowly than the Elf-1-DNA complex alone. The complex formed with each monoclonal antibody migrates with different mobility. mAb-Elf-1-DNA complexes are formed even when the monoclonal antibody supernatant is diluted $1: 250$. Nonspecific monoclonal antibodies do not lead to a shift in the mobility of the labeled DNA when they are more dilute than $1: 10$ (data not shown). $(B$ and $C)$ The immunoprecipitation of Elf-1 activity from nuclear extracts. Anti-mouse immunoglobulin coupled to Sepharose was incubated with PBS or with mAbs BF1, AE9, or anti-Golgi control (Con). The resins then were incubated with crude nuclear extract. After the incubation, the unbound protein in the supernatant was assayed for Elf-1 activity using a DNase I footprinting assay, as described in Fig. 1A. Monoclonal antibodies BF1 and AE9 deplete the extract of Elf- 1 activity. The numbers above each lane refer to the volumes of supernatant added $(\mu \mathrm{l})$. The protein bound to the resin then was incubated with a mixture of two ${ }^{32}$ P-labeled oligonucleotides: element I, which contained an Elf-1-binding site, and element II, which did not. To confirm the specificity of binding to the resin, the assay also was carried out in the presence of $50 \times$ excess specific (I) and nonspecific (II) competitor. The oligonucleotides that bound to the resin were eluted with $0.5 \mathrm{M} \mathrm{KCl}$ and analyzed on an acrylamide gel. As the autoradiograph in $C$ shows, only the resin coupled to mAbs BFl and AE9 show DNA-binding activity, and the activity is specific for element I. The difference in the levels of binding between the AE9 and BF1 resins and the low level of apparent competition by element II with the AE9 resin were not observed in other experiments.

and the in vivo Elf-1, and the DNase I hypersensitive bands induced by the binding of Elf-1 from embryos also are induced by the in vitro-synthesized protein. There is, however, an additional DNase I hypersensitive band generated by the binding of the protein from cDNA F, possibly because this is a truncated protein.

\section{Elf-1 synthesized in vitro has reduced affinity for mutated element I sites}

The identity of the cloned factor was verified further by assaying the affinity of the in vitro-translated Elf-1 for mutant element I sequences that prevent neuronal expression of $D d c$ (Bray et al. 1988). In Figure 5A we show the effect of two point mutations in the element I sequence on the expression of $D d c$ in the embryonic CNS. Both mutations inhibit the cell-specific expression of $D d c$ severely in the CNS. There is no detectable neuronal expression in strains carrying the $\mathrm{ml}$ mutation, and very low levels of expression are detected in strains carrying the $\mathrm{m} 2$ mutation. In our previous experiments (Bray et al. 1988), the effects of element I mutations were assayed in the context of a $D d c$ gene that lacked much of the proximal promoter sequences. The results presented here show that mutating only $2 \mathrm{bp}$ of element I is sufficient to abolish neuronal expression of $D d c$. This demonstrates that no other element of the wild-type $D d c$ promoter can substitute functionally for element I. The 
Bray et al.

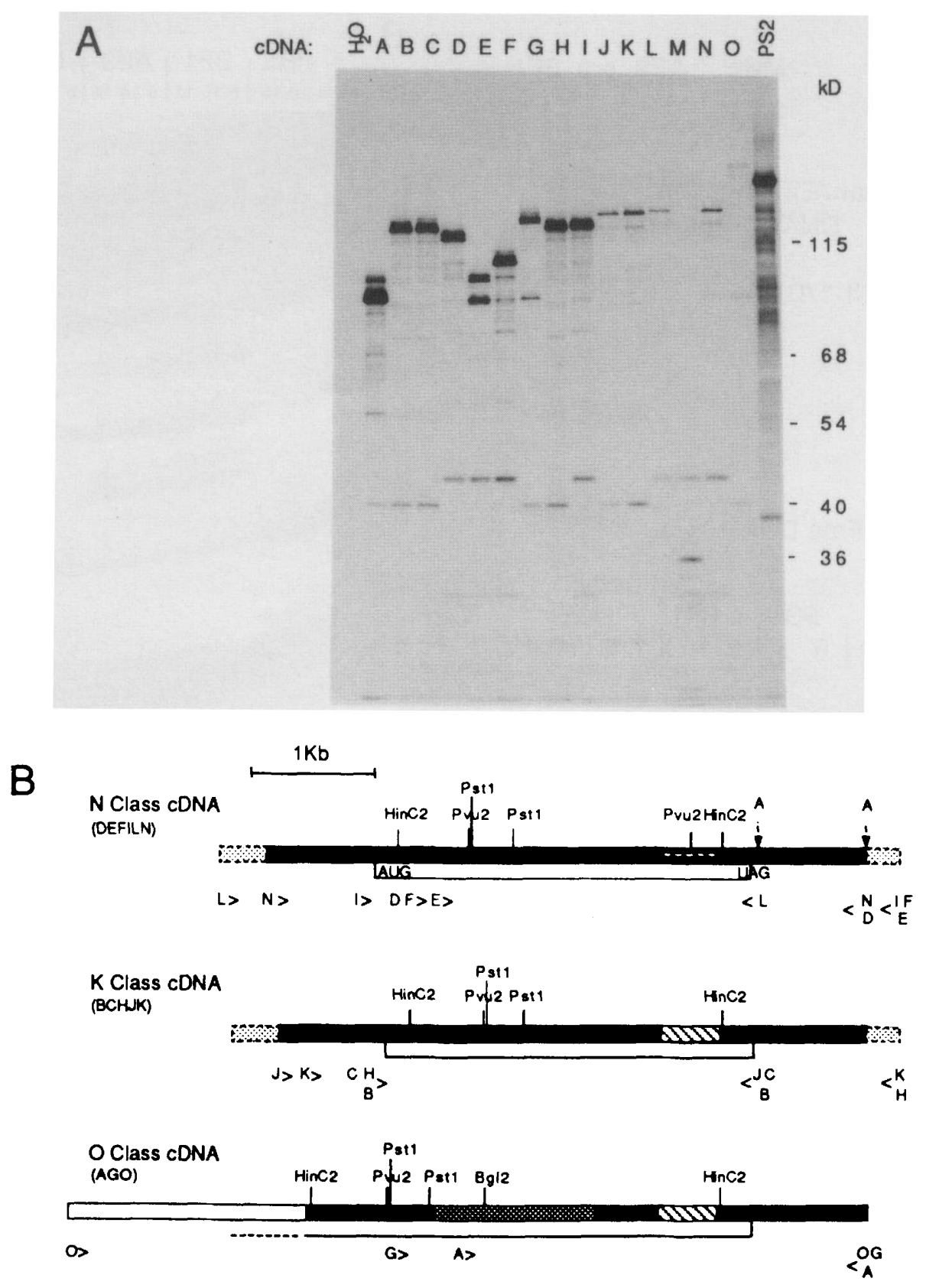

Figure 3. Analysis of cDNA clones encoding Elf-1. (A) Protein products encoded by the cDNAs isolated from 8- to 12-hr embryonic cDNA library. The cDNA clones were transcribed in vitro using SP6 polymerase, and the mRNA was translated in a message-dependent in vitro translation system from rabbit reticulocytes in the presence of $\left[{ }^{35} S\right]$ methionine. An autoradiograph of the labeled products from each cDNA analyzed on an SDS-polyacrylamide gel is shown. (Lane $\mathrm{H}_{2} \mathrm{O}$ ) Water in place of mRNA; (lane PS2) mRNA from a characterized integrin cDNA clone (Brown and Kafatos 1988). (B) Diagram of the three different classes of Elf-1 cDNAs. The DNA is represented by the shaded rectangle. For the N class cDNAs, black shading represents the extent of the DNA that has been sequenced. The stippled regions at the $3^{\prime}$ and $5^{\prime}$ ends are additional sequences present in other cDNAs of the same class that have not been sequenced. The open reading frame is indicated by the unshaded rectangle underneath the DNA. Restriction sites are marked above the DNA; (A) poly(A) tracts at which some of the cDNA clones were initiated. The letters under the diagram indicate the extent of each cDNA clone. The maps for the $\mathrm{K}$ and $\mathrm{O}$ class cDNAs are based on comparisons between the restriction sites in these clones and the $\mathrm{N}$ class cDNA clones. The restriction enzymes RsaI and BstNI were used in addition to those shown here. Regions that differ from $\mathrm{N}$ class cDNAs are indicated by hatched and heavily stippled shading and no shading.

Elf-1-binding activity in crude nuclear extracts has a lower affinity for these mutated element I sites than for the wild-type sequence. If the isolated cDNA clones encode the Elf-1 activity, their translation products should behave in a similar manner. A 50 -fold excess of the $\mathrm{m} 1$ oligonucleotide is unable to compete with the wild type for binding of the affinity-purified Elf-1 (Fig. 5B), and even a 100 -fold excess of this oligonucleotide is unable 


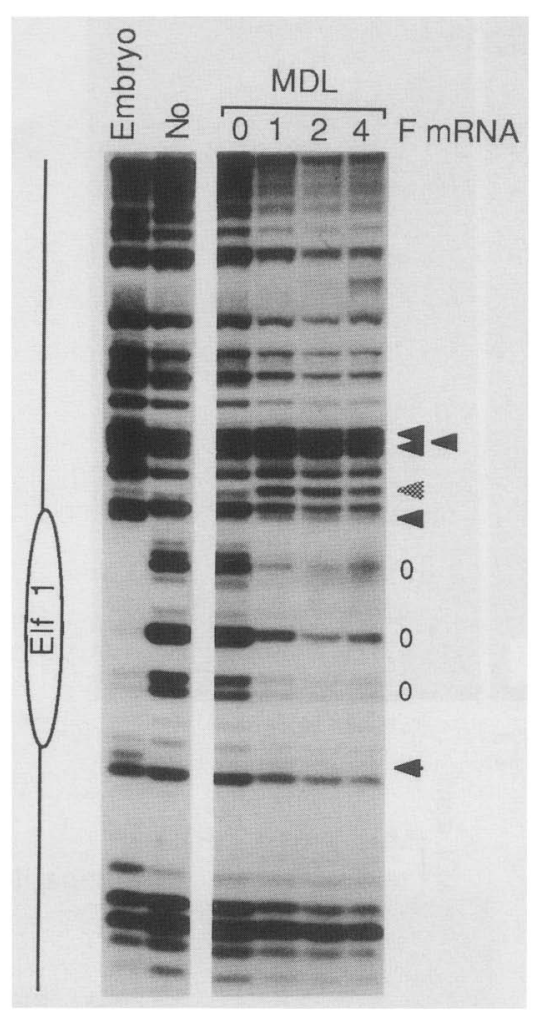

Figure 4. Protein synthesized from cDNA clone $\mathrm{F}$ in vitro has Elf- 1 footprinting activity. The cDNA clone $F$ was transcribed and translated in vitro and assayed for Elf- 1 activity in a DNase I protection assay. The in vitro translation system (MDL) contained no RNA $(0)$ or serial dilutions of in vitro-transcribed mRNA (lanes 1, 2, 4, where 4 contains the highest concentration of RNA). The RNA concentration used in lane 2 produced the highest level of protein (data not shown). The ${ }^{32}$ P-labeled DNA was a 188-bp fragment from the $D d c$ promoter containing element I. Black arrowheads indicate the bands with increased sensitivity to DNase I in the presence of protein; 0 indicates bands that are protected in the assay; the stippled arrowhead indicates a band that is hypersensitive in the presence of in vitro-synthesized Elf-1 but not in the presence of protein from embryos. The footprint produced by Elf- 1 in a crude nuclear extract (Embryo) is shown for comparison along with a lane with no added protein $(\mathrm{No})$.

to compete fully. The protein has a higher affinity for $\mathrm{m} 2$, as a 50-fold excess of this oligonucleotide competes partially with the wild type. The protein encoded by the cDNA clone gives similar results to the affinity-purified protein; a 50-fold excess of either mutated element I sequence is unable to compete fully the binding to wildtype element $\mathrm{I}$, and $\mathrm{m} 1$ is less effective than $\mathrm{m} 2$ at competing for binding (Fig. 5C). This demonstrates that the cDNA clones encode the Elf- 1 activity detected in crude nuclear extracts and that this activity correlates with the function of element $I$ in vivo.

\section{Elf-1, a distant relative of MyoD and myogenin?}

The complete DNA sequence of cDNA clone $N$, which encodes the full-length form of the protein used in Figure 4, contains a single large open reading frame encoding 1063 amino acids with a calculated molecular mass of $116 \mathrm{kD}$ (Fig. 6). When analyzed on SDS-polyacrylamide gels, the protein produced in vitro from clone $\mathrm{N}$ migrates with an apparent molecular mass greater than this, migrating slower than the highest molecular mass marker of $116 \mathrm{kD}$. The putative initiating methionine is $\sim 980 \mathrm{bp}$ from the $5^{\prime}$ end and is within a sequence (ACGTATAATG) that resembles the consensus for Drosophila proteins $\left(\mathrm{ANNC} /{ }_{\mathrm{A}} \mathrm{A}^{\mathrm{A}} / \mathrm{C}_{\mathrm{C}}^{\mathrm{A}} / \mathrm{C}_{\mathrm{C}} \mathrm{ATG}\right.$; Cavener 1987). The translation of a derivative of cDNA N, deleted to within $37 \mathrm{bp}$ of the putative initiating methionine, produces a protein of identical molecular weight to that from the full-length cDNA, supporting our identification of the initiation site (data not shown).

The amino-terminal $50 \%$ of the encoded Elf- 1 protein contains several polyglutamine stretches, the longest of which has 22 glutamine residues interrupted by one histidine. These homopolymer tracts, which have been called OPA repeats, are encoded by the codons CAG and CAA. Repeats of this kind have been found in a number of other Drosophila proteins (Poole et al. 1985; Regulski et al. 1985; Wharton et al. 1985; Crews et al. 1988), as well as in proteins from other eukaryotes (e.g., glucocorticoid receptor; Hollenberg et al. 1985; Miesfeld et al. 1986) but are of unknown function.

We searched the available data bases for protein sequences that are related to the Elf- 1 cDNA $N$ sequence and have not found any proteins that show substantial similarity to Elf- 1 . The protein does not contain a domain related to the characterized homeo box (McGinnis et al. 1984; Levine and Hoey 1988) or zinc-finger (Miller et al. 1985) DNA-binding protein motifs. However, we detected a marginal similarity (Fig. 6B) between a 90-amino-acid region in Elf- 1 and the two related proteins MyoD (Davis et al. 1987) and myogenin (Wright et al. 1989). Only a few of the conserved amino acids are the same as those conserved between this region in MyoD and the other proteins to which MyoD appears to be related, namely myc, daughterless, and achaete scute (e.g., see Caudy et al. 1988; Murre et al. 1989). However, many of the nonidentical amino acids represent conservative changes. In particular, hydrophobic residues are conserved at almost all the positions, although Elf-1 contains neither the conserved phenylalanine nor the conserved tyrosine, which are marked with asterisks in Figure 6B. Also, computer analysis of the predicted structure of the domains from Elf- $1, \mathrm{MyoD}$, and myogenin further indicate similarities between the three sequences. Two algorithms predict that Elf-1, MyoD, and myogenin will form a helix-turn-helix structure within this region (Chou and Fasman 1974; Garnier et al. 1978), as indicated in Figure 6, and analysis of hydrophobicity and flexibility of these regions also gives similar predictions for the three sequences. The similarity between these structural profiles leads us to believe that the relationship between the proteins is significant although distant. 
Bray et al.
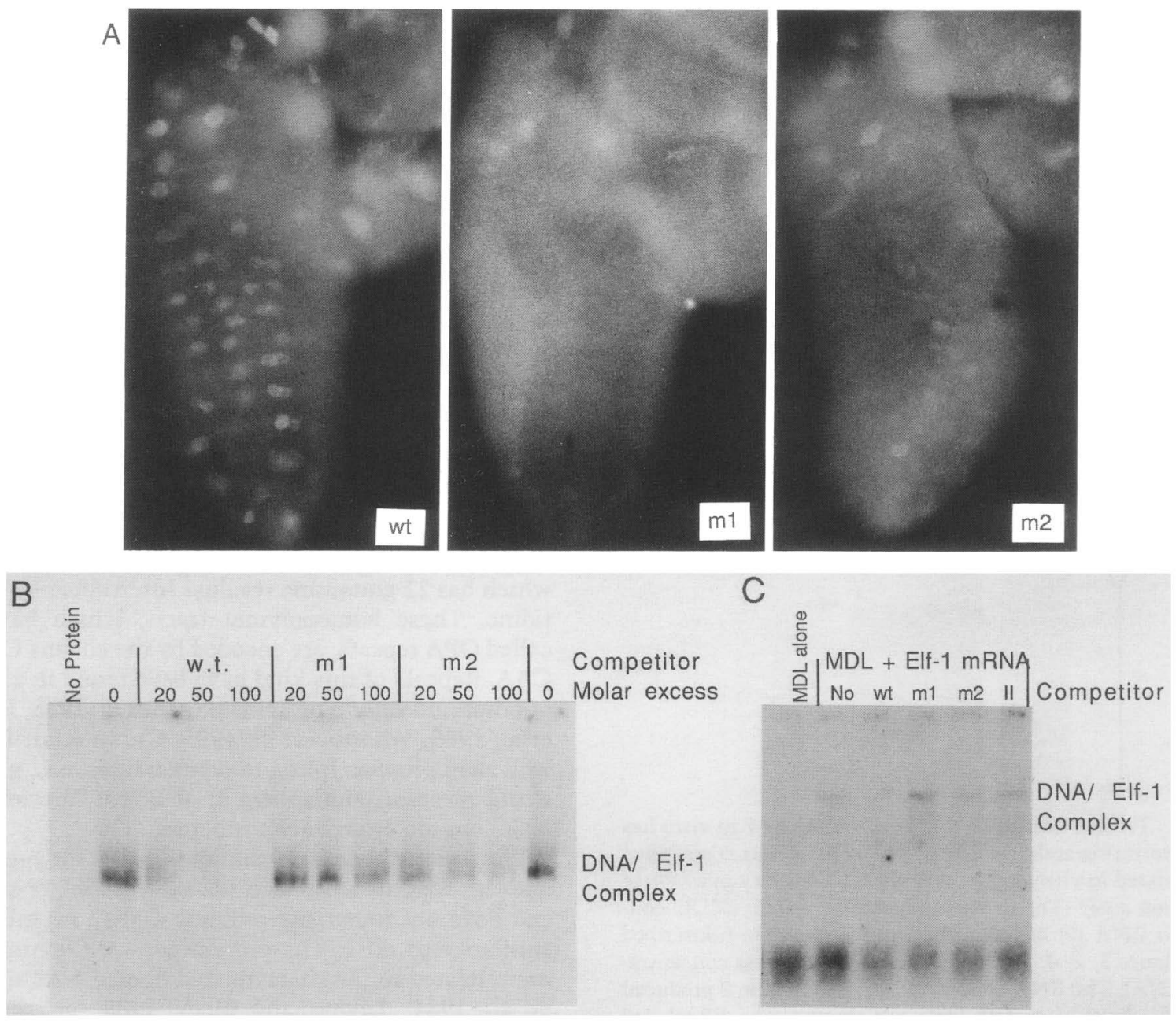

Figure 5. Native and in vitro-synthesized Elf-1 have lower affinity for mutant element I sites that prevent expression of $D d c$ in vivo. (A) CNS expression of $D d c$ genes containing mutated element I sites. In vivo expression of $D d c$ was assayed in P-element transformant strains that contained the mutant $D d c$ genes. Anti-Ddc immunofluorescent staining of CNS dissected from 20- to 24-hr embryos is shown. The CNS were from a wild-type ( $\mathrm{wt}$ ) strain or from strains with one of two mutations in element $\mathrm{I}(\mathrm{ml}$ and $\mathrm{m} 2)$. In the wild type, $D d c$ expression occurs in a segmentally repeated pattern of neurons in the ventral ganglion (condensed ventral nerve cord). No $D d c$ expression is detected in the $\mathrm{ml}$ strain, whereas a low level of expression is observed in the normal set of $D d c$-expressing neurons in the $\mathrm{m} 2$ strain. Three independent transformant lines were examined for each mutation, and all gave the phenotypes presented here. The 2-bp element I mutations were introduced into otherwise wild-type Ddc genes containing $2.2 \mathrm{~kb}$ of 5 '-flanking sequences. (B) The binding of Elf-1 to mutant element I sequences was tested in a competition assay. The Mono-Q-purified Elf-1 was incubated with a ${ }^{32} \mathrm{P}$-labeled 188-bp fragment from the $D d c$ promoter containing element $\mathrm{I}$ in the presence of the indicated molar excess of unlabeled competitor sequences. The labeled Elf-1-DNA complex analyzed on a native acrylamide gel is shown. The mutant oligonucleotides only compete with the labeled wild-type DNA when present in $50 \times$ excess, indicating that Elf- 1 has low affinity for these sites. All the competitor sequences were 25 -bp double-stranded oligonucleotides containing wild-type (wt) or mutant $(\mathrm{m} 1$ and $\mathrm{m} 2$ ) element $\mathrm{I}$ sites. The sequence of $\mathrm{ml}$ and $\mathrm{m} 2$ is given in Materials and methods. (Lanes 0 ) No added competitor. The free DNA probe has been run off the gel. $(C)$ A competition assay using Elf- 1 synthesized in vitro. The Elf- 1 cDNA was transcribed and translated in vitro (MDL + Elf-1 mRNA) and incubated with ${ }^{32} \mathrm{P}$-labeled oligonucleotide containing the element I sequence in the presence (wt, ml, m2, II) or absence (No) of competitor sequences. The competitors were the oligonucleotides described in $A$ and, in addition, a nonspecific competitor oligonucleotide (II). All were used in 50-fold molar excess. (Lane MDL alone) MDL with no added mRNA. A nonspecific band is seen near the bottom in this and all other lanes.

\section{Elf-1 expression is restricted to tissues derived from ectoderm}

We used the Elf-1 monoclonal antibodies to study the spatial expression of this protein family within Droso- phila embryos. Whole embryos incubated with mAb BF1 show Elf-1 immunoreactivity only in the CNS, the epidermis, and small regions in the fore- and hindgut, all of which are derived from ectoderm. Figure 7 shows the distribution of Elf-1 protein in stage 15 embryos 
A 1 AAAAAAAAAA AAACAACAAC AAATTGGCTT GAAAACGCAA ATGCCAGGCG AAACGCCCCC GAACCGACCC GCCCCCTCAA CTTTTGCGCC CTTCAGTTCT CAACAACGGT AGCAATAGCA 241 GAATATGGAG CAGCAGCAAC ATCAAATGTT AGGCCAAAAT GCACAAACCG CCAGCAACAA AGGCAGCACC AAGCGAACGA AACAACAACA GCTCCACATA CCACAAAGAG TGGCACATTA 361 AGGTGCACCC ACCACGAAAC AGCAACAACG GGGGCAACCAA CAACAGCAGC AGCAGCAGCA GCAGCCACAT TTCAGTTACA GCTCCAGACT CCCAGGTTGC AGACTCCCAA AGCCAAACAG

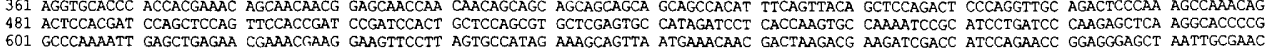

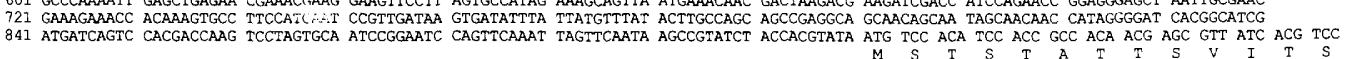

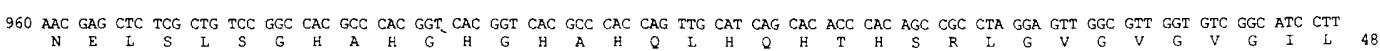

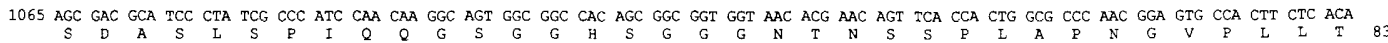

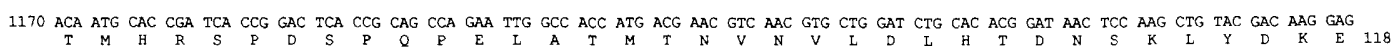
1275 GCT GTA TTT ATA TAC GAA ACG CCC AAG GTG GTG ATG CCA GCA GAT GGC GGG GGT GGC AAT AAT TCC GAT GAA GGT CAT GCC ATC GAT GCG CGG ATT GCG GCC CAA

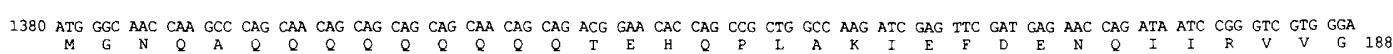

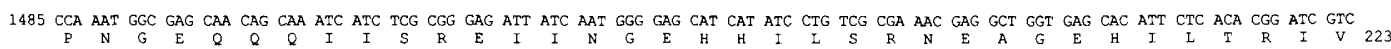
1590 AGT GAT CCC TCC AAG TTG ATG CCC AAT GAC AAT GCA GTG GCC ACG GCC ATG TAC AAC CAG GCC CAA AAG ATG AAC AAT GAT CAC GGG CAG GCG GTA TAT CAG ACA 1695 TCA CCA TTG CGC CTG GAC GCG TCT GTA TTG CAT TAT AGT GGC GGC AAT GAT TCG AAT GTG ATT AAG ACG GAG GCC GAT ATC TAC GAG GAT CAC AAG AAA CAT GCG
$\mathrm{S}$ 1800 GCT GCA GCA GCA GCT GCT GCC GGC GGA GGA TCC ATC ATA TAC ACC ACA TCC GAT CCG AAC GGA GTG AAT GTG AAA CAA CTG CCC CAT TTG ACG GTA CCC CAA AAA

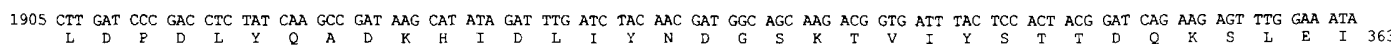

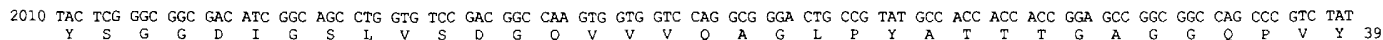
2115 ATC GTG GCC GAC GGT GCC TTG CCA GCG GGA GTC GAG GAG CAT CTG CAG AGT GGA AAG CTC AAT GGC CAG ACC ACA CCT ATC GAT GTC TCT GGC CTA TCG CAA AAT 2220 GAG ATT CAA GGC TTT TTG CTC GGC TCA CAC CCC TCG TCA TCG GCG ACG GTA AGC ACA ACC GGC GTT GTC TCC ACG ACA ACG ATC TCG CAT CAC CAG CAA CAG CAG 2325 CAG CAG CAG CAA CAG CAA CAG CAG CAG CAG CAG CAG CAA CAC CAG CAG CAG CAG CAA CAT CCC GGC GAC ATI GTT AGT GCC GCT GGC GTG GGG AGC ACG GGC TCC 2430 ATT GTC TCA TCT GCG GCG CAA CAG CAG CAG CAG CAG CAA CTA ATT AGC ATC AAA CGA GAG CCC GAA GAC TTG CGC AAG GAT CCC AAG AAT GGC AAC ATT GCC GGT 2535 GCA GCA ACA GCA AAT GGA CCC GGT TCG GTC ATA ACG CAA AAG TCC TTT GAT TAT ACG GAA TTG TGC CAG CCG GGC ACG CTG ATC GAT GCC AAT GGC AGC ATA CCC

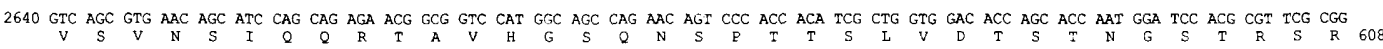
$2745 \underset{\mathrm{F}}{\mathrm{CCCC}}$ TGG CAC GAC TTT GGA CGT CAG AAT GAT GCC GAC AAA ATA CAA ATA CCA AAA ATC TTC ACA AAC GTG GGC TTC CGA TAT CAC CTG GAG AGC CCC ATC AGT TCA

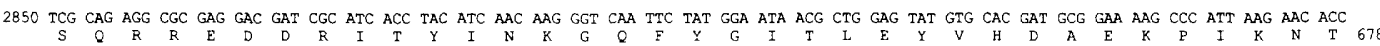
2955 ACC GTC AAG AGT GTG ATC ATG CTA ATG TTT CGC GAG GAG AAG AGT CCC GAG GAT GAG ATC AAG GCC TGG CAA TTC TGG CAC AGT CGT CAG CAT TCC GTG AAG CAG 3060 AGA ATC TTG GAT GCA GAT ACG AAG AAC TCG GT: GGC CTC GTT GGC GTC ATC GAG GAA GTG TCG CAC AAG TCC ATC GCC GTC TAC TGG AAT CCG CTG GAG AGC TCC 3165 GCC AAG ATC AAC ATT GCG GTT CAG TGC TTG AGC ACG GAT TTC AGC AGT CAA AAG GGT GTT AAG GGC CTG CCCG CTG CAC GTA CAA ATC GAC ACA TTC GAG GAC CCC 3270 AGA GAT ACG GCG GTC TTC CAC CGC GGC TAC TGT CAG ATA AAG GTC TTC TGC GAT AAG GGC GCC GAA CGA AAG ACG CGC GAT GAG GAG CGG CGG GCC GCC AAA CGA 3375 AAG ATG ACA GCC ACG GGC AGA AAG AAG CTG GAC GAG CTT TAC CAT CCG GTA ACG GAT CGG TCC GAG TTC TAT GGC ATG CAG GAC TTC GCC AAG CCG CCG GTG CTA

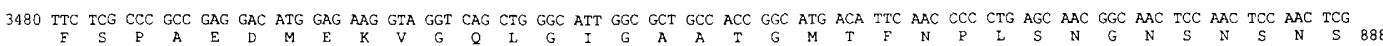

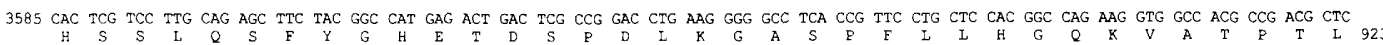
3690 AAG TTC CAC AAC CAT TTT CCG CCC GAC ATG CAG ACC GAT AAG AAG GAT CAC ATA CTG GAC CAG AAC ATG TTG ACC AGC ACA CCC CTG ACC GAC TTT GGT CCG CCG 3795 ATG AAG CGC GGC AGG ATG ACG CCG CCG ACC TCG GAG CGC GTG ATG CTG TAC GTG CGG CAG GAG AAC GAG GAG GTG TAT ACA CCG TTG CAC GTG GTG CCG CCC ACC 3900 ACG ATC GGC CTG CTA AAT GCG ATT GAA AAC AAA TAC AAB ATC TCA ACA ACG AGC ATA AAT AAC ATT TAT CGC ACA AAC AAG AAG GGG ATT ACT GCG AAA ATT GAC

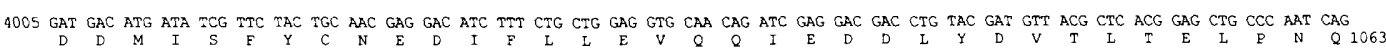

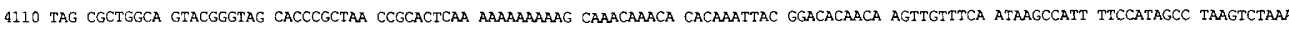
4231 TATCGTAGTT ATAATAATGG GATCCGCAAC AAATCGAGTT GCAACGGATG TTAAGAACGC TAACACAATA CGCATGTAAA ATGATACTTT AAAATTCGAT TrAGTTATTT TAGCAACAAT 4351 GAGATTATCT AAAATTGTTT GATCAAATTT TACATTCTCG CTATGTCTAT AGATAATTCT AAGCCCGTAA GCCCATAAGC GTAATCGTAA TCGTAATCGT ACCGTGTATT TATGCTCAT 4471 TATAAACAAC GATAIAIATA TATATGTGCG GAGTGCAACA GTGTCTGACC AGTAGGAGAT AAGTCGCGIT TCCGCTCCCC TGCTIATGCA MGGACCTAG GTCCAGGGCA AGTATGAGT

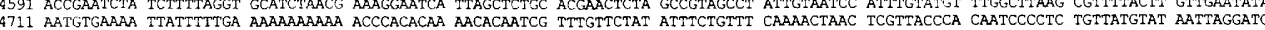
4831 TCTGTACACA AAAAAAAAA

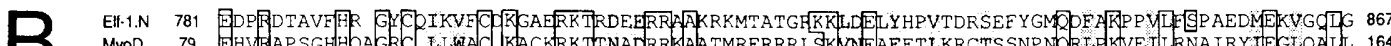

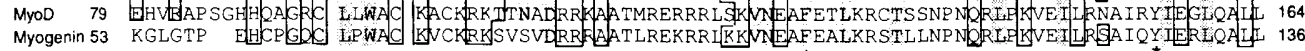

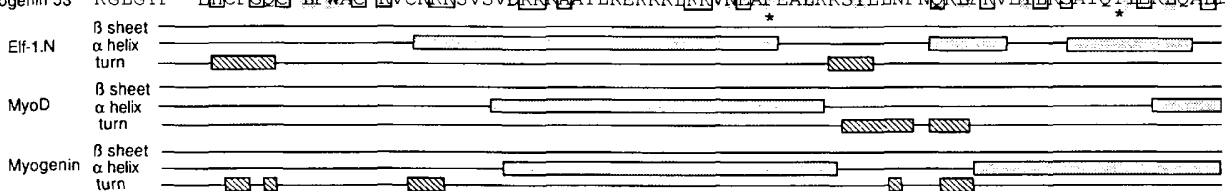

Figure 6. (See following page for legend.) 
(Campos-Ortega and Hartenstein 1985) 13-15 hr after laying, which have developed most of the structures present in the hatching larva. Elf-1 is localized clearly in nuclei, as expected for a DNA-binding protein. The majority of nuclei contain the protein in the epidermis, whereas expression of Elf- 1 is restricted to a small number of nuclei in the CNS. In the ventral nerve cord, a segmentally repeating pattern of $\sim 30$ nuclei per neuromere express Elf-1 (Figs. 7B and 8).

Expression of Elf-1 immunoreactivity is observed first in stage $11(7-9 \mathrm{hr}$ ) embryos in both the epidermis and the CNS. This agrees with the initial appearance of Elf-1 activity in nuclear extracts from 6- to $12-\mathrm{hr}$ embryos (data not shown). The expression remains fairly constant throughout the remainder of embryogenesis in the epidermis; however, the number and distribution of nuclei expressing Elf- 1 change as the embryo develops in the CNS. This is observed most clearly in the segmentally repeated structure of the ventral nerve cord. At the earliest time that Elf- 1 can be detected, it is found in a small number of medial nuclei in the ventral nerve cord: one or two per segmental neuromere (data not shown). Subsequently, more lateral nuclei express Elf- 1 in a segmentally repeated pattern, although the precise arrangement of the expressing nuclei changes as the CNS develops (Fig. 8). Later in embryogenesis $(\sim 17 \mathrm{hr}$, stage 16) the number of nuclei expressing the protein decreases, particularly in the abdominal region of the ventral nerve cord (Fig. 8), where only approximately five nuclei per segmental neuromere show Elf-1 immunoreactivity. There is little cell division during this period, but there is substantial rearrangement of the cells within the CNS. Thus, it is not clear whether these late stage neurons represent a subset of those that were expressing Elf-1 at an earlier stage or whether this is de novo expression.

\section{Double labeling with Ddc and Elf-1 antibodies}

$D d c$ is expressed only in a relatively small number of neurons in the CNS (Beall and Hirsh 1987; Konrad and Marsh 1987; see Fig. 5B|. We analyzed whether these same cells were expressing Elf-1 by incubating CNS from 18- to 22-hr embryos with both mAb BFl and an anti-Ddc rabbit serum, followed by the appropriate fluorescent- or rhodamine-conjugated secondary antibodies. By this stage the embryonic CNS has condensed in size, which involves substantial cell movement, and the number of nuclei expressing Elf-1 has decreased. At this time in development, Elf- 1 and $D d c$ are not detectable in the same cells. The majority of Elf-1-expressing nuclei in these late embryonic CNS are in the cells on the ventral and lateral extremes of the tissue, whereas the $D d c$ - expressing neurons are located more internally. Some of these neurons are in the plane of focus shown in Figure 9A. Only four nuclei in this focal plane are expressing Elf- 1 , and these do not coincide with the $D d c$-expressing neurons. Similar results were obtained with CNS from 17- to 18 -hr embryos, the earliest time that $D d c$ immunoreactivity could be detected.

We detected, however, coexpression of Elf-1 and $D d c$ in primary cultures of neuroblasts (Fig. 9B). These cells are prepared from embryos undergoing neuroblast segregation $(3-7 \mathrm{hr})$ and maintained in culture for $>18 \mathrm{hr}$, by which time they have extended axonal processes (Furst and Mahowald 1985). Only a small proportion of the neuronal cells express Elf- 1 and Ddc. Even within a cluster that contains cells expressing the two proteins, other cells exist that do not express either Elf- 1 or $D d c$ (Fig. 9B). All of the clusters that we observed expressing $D d c$ also expressed Elf-1, although it was not possible to deduce in large groups of cells whether the two proteins were present in all the same cells. One interpretation of the difference between the expression observed in vivo and that occurring in the cultured cells is that the cultured cells become arrested at an intermediate stage of development and do not differentiate fully. Thus, the observed coexpression of Elf-1 and $D d c$ in these cells could reflect a transient developmental stage that occurs during the normal differentiation of the $D d c$-expressing neurons.

\section{Discussion}

cis-acting sequences required for cell- and tissue-specific expression that have been identified in eukaryotic genes are presumed to influence transcription via DNAbinding proteins expressed in only a subset of tissues. Thus, it is important to examine the spatial distribution and function of DNA-binding proteins in the developing organism. The protein Elf-1 binds to element I in the Drosophila Ddc gene and also to sequences adjacent to the transcription start sites of Ultrabithorax (Biggin and Tjian 1988) and engrailed (Soeller et al. 1988; S.J. Bray, unpubl.). Element $\mathrm{I}$ is required specifically for expression of $D d c$ in the CNS, as mutations in element I specifically abolish neuronal expression (Bray et al. 1988; Fig. $5 \mathrm{~A})$. To address whether Elf- 1 is expressed in the developing nervous system we raised monoclonal antibodies against Elf-1 purified from embryos. Having shown by Western blotting and immunoprecipitation that the antibodies recognize the element I binding activity specifically, we used them to examine the spatial expression of Elf-1 in Drosophila embryos and to isolate cDNA clones.

Figure 6. Sequence of Elf-1 cDNA N. $(A)$ Complete nucleotide sequence of cDNA N and predicted amino acid sequence of Elf-1. (Left) Numbers denote base pairs of DNA sequence; (right) numbers denote amino acids. $(B)$ Comparison between regions within Elf-1 $\mathrm{N}$ and within the two proteins $\mathrm{MyoD}$ and myogenin. Identical amino acids are boxed, and conservative changes are shaded. Beneath the sequence are predictions of secondary structure for each protein. Stippled boxes indicate the probable extent of sequence adopting an $\alpha$-helix; shaded boxes indicate probable $\beta$-turns. No $\beta$ sheet is predicted within these regions. Structures shown are only those predicted by the algorithms of both Chou and Fassman (1974) and Garnier et al. (1978). 


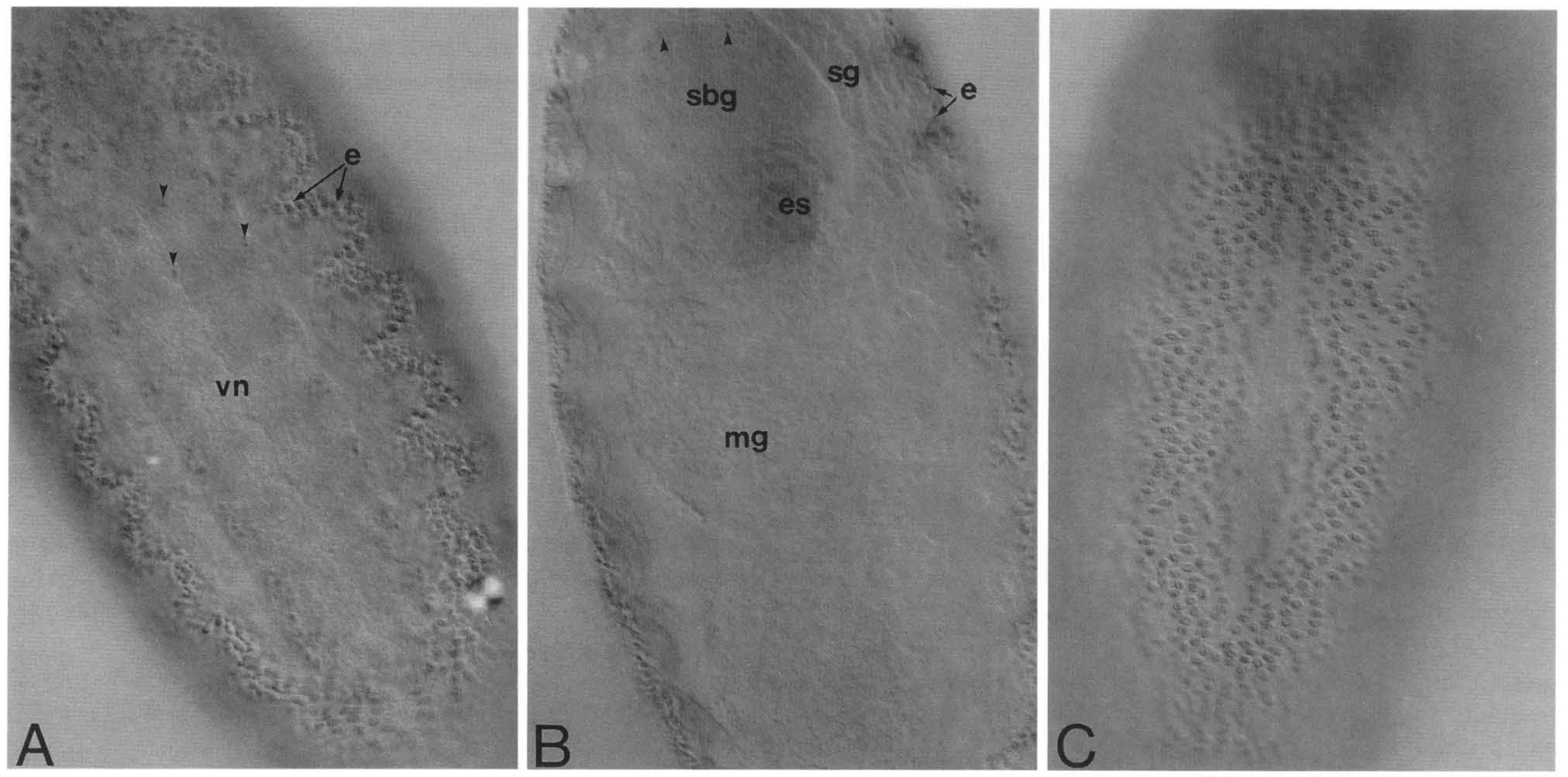

Figure 7. Expression of Elf-1 in embryos. $(A-C)$ Elf-1 immunoreactivity in 13- to 15 -hr old embryos (stage 15 according to CamposOrtega and Hartenstein 1985) detected using mAb BF1 and a horseradish peroxidase-conjugated anti-mouse secondary antibody. The embryos were mounted whole after immunohistochemistry (anterior at the top). (A) Ventral horizontal plane of focus showing the ventral surface of the CNS. Nuclear staining of Elf-1 is visible in both the epidermis (e) and a subset of nuclei in the ventral nerve cord (vn) of the CNS. Examples of three stained nuclei in the nerve cord are marked with arrowheads. $(B)$ Midhorizontal plane of focus showing the midgut (mg) salivary glands (sg), which do not contain Elf-1. Nuclear staining of Elf-1 is present in the epidermis (e), esophagus (es), and on the upper surface of the subesophageal ganglion (arrowheads, sbg). (C) Dorsal surface of a different embryo showing epidermal nuclei expressing Elf-1. Dorsal closure of the epidermis is almost complete. Magnification, $176 \times$.

\section{Expression of Elf-1 in the embryo}

Elf-1 is expressed in the nuclei of a subset of tissues in the embryo, predominantly the epidermis and the CNS. The tissue distribution of Elf- 1 is distinct from that observed for the putative transcription factors of the homeotic and segmentation gene classes. These genes are expressed in metamerically repeated patterns in a number of different tissues (for review, see Ingham 1988; Scott and Carroll 1987). Elf- 1 is expressed only in a repeating pattern in one tissue, the nervous system. In the epidermis, expression is uniform, occurring in apparently all nuclei from stage $11(7-9 \mathrm{hr})$ of development onward. In the CNS, Elf- 1 is restricted to a small number of nuclei, $\leqslant 7 \%$ of the nuclei in a segmental neuromere, and its expression undergoes distinct changes during the development of the nervous system. This is particularly dramatic during the later stages of nervous system development when the number of nuclei expressing Elf-1 per abdominal neuromere decreases from $\sim 30$ to $\sim 5$.

\section{Function of Elf-1: a transient role in the CNS expression of Ddc?}

Mutations or deletions of the Elf-1-binding site prevent neuronal expression of $D d c$ (Scholnick et al. 1986; Bray et al. 1988), suggesting that Elf-1 is involved in the regulation of $D d c$ expression in the CNS. Much of our data support this function. First, both Elf-1 purified from em- bryos and Elf-1 synthesized in vitro bind specifically to element I and have lower affinity for sequences containing mutations that eliminate neuronal $D d c$ expression. Second, monoclonal antibodies that recognize all of the proteins associated with Elf- 1 activity can deplete fully nuclear extracts of proteins binding to element I. Finally, Elf-1 and $D d c$ are coexpressed very selectively in cultures of neural cells when examined by double immunostaining with Elf-1 and Ddc antibodies. However, although Elf-1 is expressed in specific nuclei in the CNS, the two proteins are not detected in the same cells in the late embryonic nervous system. Taken together, the results suggest that Elf-1 activity in vivo may be required only at high levels transiently to activate the expression of $D d c$ in the CNS. If this is correct, a subset of the cells that express Elf- 1 at $16 \mathrm{hr}$ will go on to synthesize $D d c$ protein. The number of cells that express Elf- $I$ decreases just as $D d c$ is detected first, and the lag between the change in Elf-1 pattern and the first detectable $D d c$ immunoreactivity is $\sim 1 \mathrm{hr}$; therefore, it is possible that Elf- 1 is present when $D d c$ mRNA first appears in these neurons. The CNS form of Ddc mRNA (Morgan et al. 1986) is detectable first in 16- to 18-hr embryos (C.J. Beall, B.A. Morgan, and J. Hirsh, unpubl.|. Our data also suggest that Elf-1 activity is more stable in these cultured cells or that the cultured neural cells are arrested at a developmental stage that is only transient in the embryo. This finding highlights the importance of studying putative transcription factors in vivo. 


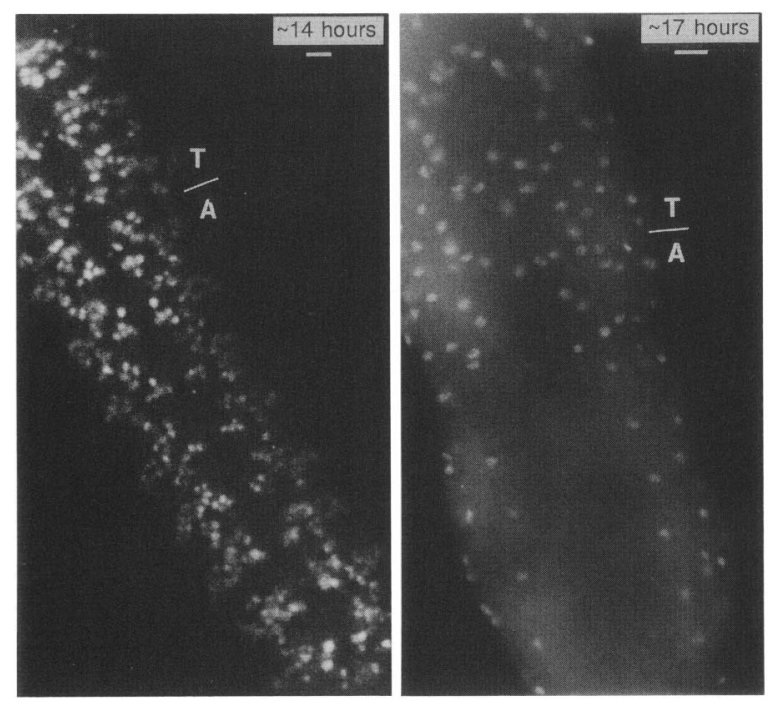

Figure 8. Expression of Elf-1 in the embryonic CNS. Elf-1 distribution in the ventral nerve cord of isolated CNS from 14-hr, stage-15 embryos and 17-hr, stage-16 embryos. In the 14-hr nerve cord, antibody localization was detected histochemically, but the photograph has been printed in negative contrast to facilitate comparison with the immunofluorescence in the 17-hr nerve cord. The approximate boundary between the thoracic $(T)$ and abdominal $(\mathrm{A})$ segmental neuromeres is indicated in each. The pattern of nuclei containing Elf- 1 is different in the nerve cords at the two stages, particularly in the more posterior abdominal neuromeres. Both show a segmentally repeating pattern. The plane of focus in both photographs is close to the ventral surface of the nerve cord (anterior is to the top). Bars, 10 $\mu \mathrm{m}$.

The formation of stable active transcription complexes in differentiated cells has been proposed by others (Brown 1984; Weintraub 1985). Recent experiments in vitro demonstrated also that the factor ATF is required for the formation of an active transcription complex but may not be required for its maintenance, although the capacity of the complex for reinitiation was not addressed (Hai et al. 1988; Horikoshi et al. 1988). It is important to note that cell division in the CNS has ceased in almost all cells by $15 \mathrm{hr}$ (Campos-Ortega and Hartenstein 1985), and if an active transcription complex is formed at this time it will be able to persist without interruption from DNA replication. As the majority of Ddc embryonic neurons appear to persist even during metamorphosis, a complex formed in those cells would not encounter any further DNA replication during the rest of development. There are protein-binding sites in the distal $D d c$ enhancer which, when mutated, give a similar phenotype to element I, namely total loss of neuronal expression (Johnson et al. 1989; W.A. Johnson and J. Hirsh, in prep.). It is possible that one of these proteins is activated subsequent to Elf- 1 and functions to maintain the neuronal expression of $D d c$. Thus, the mechanisms that regulate $D d c$ expression in the CNS may resemble those involved in homeotic gene expression (e.g., see Scott and Carroll 1987). Transiently expressed segmentation genes appear to be involved in initiating the pattern of homeotic gene expression (Duncan 1986), and, subsequently, other proteins are required to modify and to maintain the pattern of expression (Struhl and Akam 1985).

There are several alternative explanations for the observations presented here. There may be an additional element I-binding factor that is expressed in the $D d c$-expressing neurons. There are at least two independent proteins that can bind to the octamer sequence in immunoglobulin genes (Fletcher et al. 1987; Scheiderecht et al. 1987; Staudt et al. 1988), and a number of different proteins bind to the CAAT box sequence (Johnson et al. 1987; Chodosh et al. 1988; Santoro et al. 1988). However, if an additional element I-binding protein does exist, it must be present at much lower abundance or be unstable under conditions of isolation, as we have not detected any other activity separable from Elf-1. Other

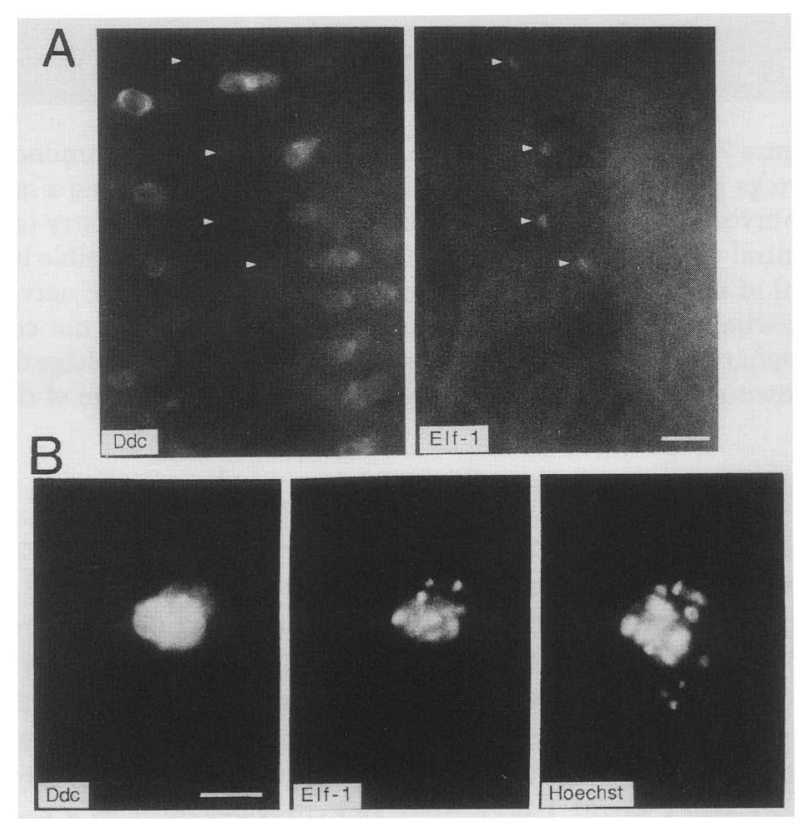

Figure 9. Expression of Elf-1 and $D d c$ in embryonic CNS and in cultured neuroblasts. $(A)$ Embryonic CNS dissected from 20-hr embryos were incubated with both an anti-Ddc rabbit antiserum (Ddc) and mAb BFl (Elf-1). The antibodies were detected using rhodamine- and fluorescein-conjugated secondary antibodies, respectively. The $D d c$-expressing neurons in the plane of focus are the serotonin-expressing neurons from T1-A5 (anterior is to the top). The same plane of focus reveals only four nuclei expressing Elf-1, whose position is marked by white arrowheads. No cells contain both $D d c$ and Elf-1. Bar, $10 \mu \mathrm{m}$. (B) Neuroblasts from $\sim 4.5$-hr embryos were separated from other cell types on the basis of their size and maintained in culture for $18 \mathrm{hr}$. The cultured cells were incubated with anti$D d c$ serum (Ddc) and mAb BF1 (Elf-1), followed by rhodamineand fluorescein-conjugated specific secondary antibodies. Hoechst staining of DNA was used to detect all nuclei. A cluster of neural cells is shown, which probably derived from several neuroblasts. Both Elf- 1 and $D d c$ are detectable in the same cells, with Elf- 1 in the nucleus and $D d c$ in the cytoplasm. Some of the cells detected by Hoechst staining are not expressing either protein. Bar, $10 \mu \mathrm{m}$. 
explanations are that Elf- 1 is expressed in the $D d c$ neurons at a level not detected by the antibody-labeling techniques we used or that the antibody epitopes are masked in these cells by interactions with other molecules. The inactivation of the Elf-1 gene in vivo will be required to prove formally that the proteins we purified and cloned are indeed responsible for activating $D d c$ expression in the CNS.

Elf- 1 also is expressed in the epidermis, although our previous results indicated that Elf-1 function is not normally critical for epidermal expression of $D d c$ (Scholnick et al. 1986; Bray et al. 1988). It is possible that Elf-1 does interact with element $I$ in the epidermis but that this function is not essential for expression in this tissue as a result of redundancy in the regulatory mechanisms. This is supported by the observations that sequences adjacent to element I are required for $D d c$ expression in the epidermis (Scholnick et al. 1986) and that epidermal expression of mutated $D d c$ genes that lacked many of these sequences can be stimulated by element I (Bray et al. 1988). The other genes to which Elf-1 has been shown to bind, Ultrabithorax and engrailed, are expressed in both the epidermis and CNS, but it remains to be elucidated whether any aspect of the complex pattern of expression of these genes is regulated by Elf- 1 .

\section{Multiple isoforms of Elf-1 in the embryo}

There are at least three isoforms of Elf-1 present in embryos. Analysis of 15 different cDNA clones encoding Elf-1 reveals at least three different forms of Elf-1 mRNA. The variations between the classes are within coding sequences and are most likely generated by alternate splicing, as the cDNAs have extensive sequences in common and derive from a single locus at $54 \mathrm{~F}$ on the second chromosome (data not shown). A number of polypeptides copurify with Elf-1 activity from nuclei of Drosophila embryos. These polypeptides are all related, because the purified proteins share epitopes recognized by our two independent monoclonal antibodies. The three different cDNA classes account for some of the polypeptides observed in the purified preparation of Elf- 1 from embryos. However, several of the affinity-purified polypeptides are smaller than those encoded by the cDNAs. These may represent additional isoforms of Elf-1 or may result from proteolysis of the detected fulllength variants.

The differences between the proteins encoded by the different Elf- 1 cDNAs could influence their activity in a number of ways. The isoforms may have different binding specificities in vivo, although our preliminary experiments have not revealed any substantial differences in vitro. Alternatively, or in addition, the sequences could affect the interactions between the Elf-1 DNA-binding protein and other proteins. It is clear that the interaction between protein factors is an important aspect of gene regulation, as demonstrated by the formation of heterodimers and by cooperativity between factors (e.g., Tsai et al. 1987; Halazonetis et al. 1988; Nakabeppu et al. 1988; Treizenberg et al. 1988; Lillie and Green 1989; Poellinger and Roeder 1989; also see Ptashne 1988). It is also possible that the alternate protein products represent tissue-specific forms of this DNA-binding protein. Further analysis will require preparation of antibodies that are specific for each isoform.

The amino portion of the 1063 amino acids encoded by Elf- 1 cDNA $N$ contains several polyglutamine tracts. Similar polyglutamine tracts have been found in other Drosophila proteins, all of which have important roles in Drosophila development (Poole et al. 1985; Regulski et al. 1985; Wharton et al. 1985; Crews et al. 1988), although the function of the repeats is unknown. In Elf-1, the longest glutamine repeat is located in the middle of the protein and may form a flexible hinge between the amino and carboxyl domains. Wharton et al. (1985) suggested that the tendency of the hydrophilic glutamine residues to reside on the surfaces of globular proteins could impose an increased susceptibility of these polyglutamine sequences toward proteolysis. The smallest protein we observe in the purified Elf- 1 fractions is $\sim 54$ $\mathrm{kD}$, which could correspond to the carboxy-region domain of the proteins. It is within the carboxy-region domain that the sequence similarity to MyoD is observed. A number ofother proteins show strong sequence similarity to the same portion of the MyoD protein, and it appears that this conserved region represents a DNAbining domain (Murre et al. 1989).

Although the function of Elf-1 in regulating $D d c$ remains to be elucidated fully, it is clear that the Elf-1 proteins are expressed only in the nuclei of certain tissues within the embryo. These tissues, namely the CNS, the epidermis, and the fore- and hindgut, are all of ectodermal origin. Expression of Elf- 1 in the nervous system appears to be regulated stringently in a cell-specific fashion, and it seems likely that this family of DNAbinding proteins has a distinct function in the development of the CNS. Now that we isolated cDNA clones encoding Elf- 1 and located the Elf-1 gene, it will be possible to assess its importance during development using a genetic approach.

\section{Materials and methods}

Restriction enzymes and other enzymes used for molecular biology were purchased from New England Biolabs or Boehringer-Mannheim Biochemicals, and procedures were performed as described by Maniatis et al. (1982), except where otherwise noted. SP6 RNA polymerase was purchased from Bethesda Research Laboratories. Column materials were from Pharmacia or Sigma. DNase I protection assays were carried out as described previously (Heberlein et al. 1985; Bray et al. 1988), using DNase I from Worthington. The DNA fragment used was a 188-bp EcoRV-Ncol fragment from the Ddc gene promoter that was labeled with ${ }^{32} \mathrm{P}$ at the $N$ col site using polynucleotide kinase. The SDS-polyacrylamide gels used to analyze proteins (either 12.5 or $15 \%$ ) were as described by Anderson et al. (1973) and were either silver-stained or transferred electrophoretically to nitrocellulose (Towbin et al. 1979; Brown and Kafatos 1988). Oligonucleotides were synthesized by Dr. Alex Nussbaum, using an Applied Biosystems synthesizer. Oligonucleotides used in the in vitro DNA-binding assays consisted of complementary oligonucleotides that generated $\mathrm{Xba}$ sticky ends when 
annealed. The sequences of the upper strands were as follows: wild-type element I, CTAGAGCGATTGAACCGGTCC TGCGGT; ml, CTAGAGCGATTGATCGGGTCCTGCGGT; m2, CTAGAGCGATAGTACCGGTCC TGCGGT; element II, CTAGAGTTCAGCGGCTGCGGACT (see Fig. 1 and Bray et al. 1988). Oligonucleotides used for in vitro mutagenesis of the $D d c$ gene were single-stranded 26-mers generating the same element I mutations as those in the double-stranded competitor oligonucleotides (boldface type).

\section{Purification of Elf-1 from embryos}

Embryos were collected from populations of wild-type Canton S Drosophila melanogaster. Collections of 0- to 12 -hr embryos were aged for an additional $10 \mathrm{hr}$ at $25^{\circ} \mathrm{C}$ and then stored at $4^{\circ} \mathrm{C}$ for up to 3 days. All subsequent procedures were conducted at $4^{\circ} \mathrm{C}$. Nuclear proteins were prepared from the aged embryos, as described by Heberlein and Tjian (1988). We started routinely with 100- to 150-gram embryos. The nuclear proteins from two such collections were pooled and applied to a 35- $\mathrm{ml}$ heparinagarose column in $0.1 \mathrm{M} \mathrm{KCl} \mathrm{HEMG} \mathrm{[} 25 \mathrm{mM}$ KHEPES (pH 7.6), $0.1 \mathrm{~mm}$ EDTA, $2.5 \mathrm{~mm} \mathrm{MgCl}_{2}, 10 \%$ (vol/vol) glycerol, $1 \mathrm{~mm}$ dithiothreitol, $0.2 \%$ (wt/vol) $\mathrm{Na}_{2} \mathrm{~S}_{2} \mathrm{O}_{5}$; note this buffer contains less $\mathrm{MgCl}_{2}$ than that used by Heberlein and Tjian 1988]. The column was washed extensively and then eluted with $0.4 \mathrm{M}$ $\mathrm{KCl}$ HEMG, and the pooled protein eluted from the column was dialyzed extensively against $0.1 \mathrm{M} \mathrm{KCl} \mathrm{HEMG.} \mathrm{The} \mathrm{yield}$ from 250 -gram embryos was $\sim 250$-mg of this heparin-agarose fraction, which we refer to in the text as crude nuclear extract.

The heparin-agarose fraction was chromatographed on a 15-ml DNA cellulose column. The protein was applied in $0.1 \mathrm{M}$ $\mathrm{KCl}$ HEMG, and the washed column was eluted with a linear gradient of $0.1-0.75 \mathrm{M} \mathrm{KCl}$. The eluted fractions were assayed for Elf- 1 activity using a DNase I protection assay. The activity eluted between 0.3 and $0.4 \mathrm{M} \mathrm{KCl}$. The majority of the protein bound to the column eluted between 0.2 and $0.3 \mathrm{M} \mathrm{KCl}$, allowing $\sim 100$-fold purification of Elf- 1 activity. Total protein in the pooled active fractions was usually $\sim 1 \mathrm{mg}$. In later rounds of purification, often we eluted the activity from the DNA cellulose column with a step elution between 0.3 and $0.45 \mathrm{M} \mathrm{KCl}$. The pooled active fractions were dialyzed against $0.1 \mathrm{M} \mathrm{KCl}$ HEMG.

The Elf- 1 was purified from the active DNA cellulose column fraction using a sequence-specific resin. The double-stranded element I oligonucleotide was constructed with $\mathrm{Xba}$ sticky ends to facilitate ligation of the oligonucleotide into polymers. These were coupled to cyanogen bromide-activated Sepharose using the procedure described by Kadonaga and Tjian (1986). The active fraction from the DNA cellulose column was incubated with $0.4 \mathrm{U} / \mathrm{ml}$ of poly[d(I-C)] (Pharmacia) for 15-30 min on ice and then applied to a $0.5-\mathrm{ml}$ element I column in $0.1 \mathrm{M}$ $\mathrm{KCl}$ HEMG that contained $0.1 \% \mathrm{NP}-40$. The column was washed with $0.25 \mathrm{M} \mathrm{KCl} \mathrm{HEMG} \mathrm{and} 0.1 \% \mathrm{NP}-40$, and the Elf- 1 was eluted with $0.5 \mathrm{M} \mathrm{KCl} \mathrm{HEMG} \mathrm{and} 0.1 \% \mathrm{NP}-40$. The eluted protein was diluted to $0.1 \mathrm{M} \mathrm{KCl}$, incubated with $0.4 \mathrm{U} / \mathrm{ml}$ of poly $[\mathrm{d}(\mathrm{I}-\mathrm{C})]$, and applied to an identical column and eluted in the same manner. The eluted protein was dialyzed against 0.1 M KCl HEMG. The estimated yield was $1-2 \mu \mathrm{g}$ of protein, retaining $\sim 15-20 \%$ of the starting activity, resulting in a 15,000 to 20,000-fold purification. Most of the protein used to immunize mice was of this purity.

When Elf-1 was to be purified further on an FPLC Mono Q column, it was dialyzed against $50 \mathrm{mM} \mathrm{KCl}$ TEG $[25 \mathrm{mM}$ Tris$\mathrm{Cl}$ (pH 7.6), $0.1 \mathrm{mM}$ EDTA, 10\% glycerol, $1 \mathrm{~mm}$ dithiothreitol] in the presence of $0.25 \mathrm{mg} / \mathrm{ml}$ of bovine insulin (Sigma) as carrier protein. The protein was loaded onto a $1-\mathrm{ml}$ Mono $Q$ column in the $50 \mathrm{mM} \mathrm{KCl} \mathrm{TEG} \mathrm{buffer} \mathrm{and} \mathrm{eluted} \mathrm{with} \mathrm{a} \mathrm{linear}$ 0.05 to $0.5 \mathrm{M} \mathrm{KCl}$ gradient. The insulin flowed through the column without binding. The Elf- 1 activity eluted from the column between 0.2 and $0.25 \mathrm{M} \mathrm{KCl}$, as shown in Figure 1 .

\section{Immunization and fusion procedures}

Seven-week-old $\mathrm{Rb}(8.12) 5 \mathrm{Bnr}$ mice were immunized intraperitoneally with 250-500 ng of element I affinity-purified Elf- 1 in complete Freund's adjuvant, followed by a similar quantity 3 weeks later in incomplete adjuvant. Ten days after this second injection, a small blood sample was taken from each animal and tested for anti-Elf-1 activity (see below). Ten days later, each positive animal was given a boost of $250-500 \mathrm{ng}$ of Mono Q-purified Elf- 1 in PBS $\left(130 \mathrm{mM} \mathrm{NaCl}, 7 \mathrm{mM} \mathrm{Na}_{2} \mathrm{HPO}_{4}, 3 \mathrm{~mm}\right.$ $\mathrm{NaH}_{2} \mathrm{PO}_{4}$ ). Four days after this final boost, the spleen was removed from each animal, and the dissociated cells were fused with the FOX NY myeloma cell line (Taggart and Samloff 1982), according to the procedures described by Galfre et al. (1977). The hybridomas were distributed into three 96-well microtitration plates and selected in adenine/aminopterin/thymidine (AAT) medium, as described by Taggart and Samloff (1982). Cultures positive for anti-Elf-1 activity were identified by the bandshift assay described below and cloned three times by limiting dilution over a thymocyte feeder layer. Monoclonal antibodies employed in all subsequent experiments consisted of culture medium from $3 \times$ cloned hybridomas.

\section{Screening monoclonal antibodies}

The monoclonal antibodies were assayed for Elf- 1 reactivity using a gel mobility assay, scoring for the ability of the monoclonal antibody supernatant to retard the mobility of an Elf-1DNA complex in a native polyacrylamide gel. One microliter $(\sim 0.3-0.5 \mathrm{ng})$ of affinity-purified protein was incubated with 1 $\mu l$ of diluted serum or diluted monoclonal supernatant with 0.1 $\mathrm{M} \mathrm{KCl} \mathrm{HEMG} \mathrm{added} \mathrm{to} \mathrm{a} \mathrm{final} \mathrm{volume} \mathrm{of} 3.5 \mu \mathrm{l}$. After $1-3 \mathrm{hr}$ at $0^{\circ} \mathrm{C}, 1.5 \mu \mathrm{l}$ of a mixture containing ${ }^{32} \mathrm{P}$-labeled DNA probe encompassing the element I site was added and the incubation continued for $20-30 \mathrm{~min}$. The mixture was as follows: $1 \%$ (wt/ vol) polyvinyl alcohol, $1 \times 10^{-4}$ unit of poly[d(I-C)], $\sim 50-100$ pg ${ }^{32} \mathrm{P}$-labeled DNA. After the incubation, the complexes were analyzed on a $5 \%$ native polyacrylamide gel in $89 \mathrm{~mm}$ Trisborate $(\mathrm{pH} 8)$ and $2 \mathrm{~mm}$ EDTA, and the gel was dried and autoradiographed. Bandshift assays in the absence of antibodies contained affinity-purified protein and the DNA mixture in the same proportions described, and either $\mathrm{H}_{2} \mathrm{O}$ or competitor oligonucleotides as stated. For some assays $10 \mathrm{pg}$ of ${ }^{32} \mathrm{P}$-labeled oligonucleotide was used in place of the DNA probe.

\section{Immunoprecipitation with monoclonal antibodies}

All incubations and washes were at $4^{\circ} \mathrm{C}$. Monoclonal antibody supernatant $(10 \mathrm{ml})$ or PBS (130 $\mathrm{mM} \mathrm{NaCl}, 7 \mathrm{mM} \mathrm{Na}_{2} \mathrm{HPO}_{4}, 3$ $\mathrm{mM} \mathrm{NaH} \mathrm{PO}_{4}$ ) was incubated with Sepharose-conjugated antimouse immunoglobulins (Hyclone) overnight on a rotator. The resin was washed extensively with PBS and then equilibrated in $0.1 \mathrm{M} \mathrm{KCl} \mathrm{HEMG.} \mathrm{Ten} \mathrm{microliters} \mathrm{of} \mathrm{this} \mathrm{resin} \mathrm{was} \mathrm{incubated}$ with $100 \mu \mathrm{l}$ of crude nuclear extract for $2-3 \mathrm{hr}$ with rotation. The supernatant then was removed and assayed for Elf-1 by DNase I footprinting. The resin was washed extensively with $0.1 \mathrm{M} \mathrm{KCl} \mathrm{HEMG}$, and $100 \mu \mathrm{l}$ of mixture that contained ${ }^{32} \mathrm{P}-\mathrm{la}$ beled oligonucleotides was added. The mixture contained $2 \mathrm{ng}$ of ${ }^{32} \mathrm{P}$-labeled element I oligonucleotide, $2 \mathrm{ng}$ of ${ }^{32} \mathrm{P}$-labeled element II oligonucleotide, and 0.1 unit of poly[d(I-C)] in $0.1 \mathrm{M} \mathrm{KCl}$ HEMG. Where cold competitor oligonucleotides were added, 
this was present at 50 -fold molar excess over the labeled oligonucleotides. After $30 \mathrm{~min}$ at $0^{\circ} \mathrm{C}$, the supernatant was removed and the resin was washed with $0.1 \mathrm{KCl} \mathrm{HEMG.} \mathrm{After}$ extensive washing, $25 \mu \mathrm{l}$ of $0.5 \mathrm{M} \mathrm{KCl} \mathrm{HEMG} \mathrm{was} \mathrm{added} \mathrm{to}$ eluate-bound oligonucleotides, and the resin was allowed to sit for several minutes. The supernatant was removed and a small aliquot was analyzed on a $10 \%$ native acrylamide gel, which was dried and autoradiographed.

\section{Isolation of cDNA clones}

A $\lambda$ gt 11 library prepared from 0 - to 24 -hr embryos (a gift of Tao Hsieh, Duke University) was screened for Elf-1 immunoreactivity using the procedures described by Huynh et al. (1985). Approximately 500,000 plaques were screened in total. All incubations were carried out at $4^{\circ} \mathrm{C}$. The monoclonal antibody supernatant was diluted by threefold for the screening and was incubated with the filters overnight. The secondary antibody was an alkaline phosphatase-conjugated goat anti-mouse (BioRad) used at a dilution of $1: 3000$, the assay used to detect alkaline phosphatase contained $0.3 \mathrm{mg} / \mathrm{ml}$ of nitroblue tetrazolium and $0.15 \mathrm{mg} / \mathrm{ml}$ of 5-bromo-4-chloro-3-indolyl phosphate in $100 \mathrm{mM}$ Tris-Cl (pH 9.5), $100 \mathrm{mM} \mathrm{NaCl}$, and $5 \mathrm{~mm} \mathrm{MgCl}_{2}$. DNA was prepared from plaque-purified phage, and the inserts were excised with EcoRI and purified by electrophoresis on a low-melt agarose gel. The purified DNA fragment was nicktranslated and used to screen an 8- to 12-hr embryonic cDNA library that was constructed unidirectionally in a vector, pNB40, so that the SP6 RNA polymerase promoter is the $5^{\prime}$ end of the cDNA insert (Brown and Kafatos 1988). Preparation of plasmid DNA and in vitro transcription and translations also were described by Brown and Kafatos (1988). An aliquot $(\sim 2.5 \mu \mathrm{g})$ of plasmid DNA was transcribed in vitro and the incubation was terminated by phenol extraction and ethanol precipitation of the nucleic acids. The RNA was resuspended in 2 $\mu \mathrm{l}$ of $\mathrm{H}_{2} \mathrm{O} ; 1 \mu \mathrm{l}$ of this was added to $20 \mu \mathrm{l}$ of a reticulocyte lysate message-dependent in vitro translation system $(\mathrm{MDL}$, Jackson and Hunt 1983). For the cDNA F footprinting experiment, serial twofold dilutions into MDL mixture were made so that the final incubations contained $0.5,0.25$, and $0.125 \mu \mathrm{l}$ of transcribed RNA. The entire 10- $\mu$ l sample was used for the DNase I protection assay, and $0.5 \mu \mathrm{l}$ was used for the gel mobility shift assays.

\section{DNA sequencing}

The Elf- 1 cDNA clone $\mathrm{N}$ was excised from the pNB40 vector DNA and subcloned into Bluescript vectors (Stratagene) in both orientations. Two series of overlapping deletions were constructed using exonuclease III, according to the method of Henikoff (1984). Most of the sequence was obtained using singlestranded template DNA. The Bluescript plasmids were induced to produce phage using the M13 helper phage M13KO7 (Pharmacia). The DNA sequence was determined by the dideoxy sequencing method using modified T7 DNA polymerase (Tabor and Richardson 1987). DNA sequence was analyzed using DNA Strider (Marck 1988) and the IBI Pustell sequence analysis programs. The latter was used to screen sequences in the NBRF and GenBank data bases.

\section{Antibody staining of embryos and neuroblasts}

Embryos $<15 \mathrm{hr}$ were dechorionated, fixed, devitellinized, and incubated with primary antibody, essentially as described by Dequin et al. (1984), except the buffer used for washing and incubations was BSS [10 mM tricine base, $55 \mathrm{~mm} \mathrm{NaCl}, 40 \mathrm{~mm}$
$\mathrm{KCl}, 7 \mathrm{mM} \mathrm{MgCl}, 5 \mathrm{mM} \mathrm{CaCl}, 20 \mathrm{~mm}$ glucose, $50 \mathrm{~mm}$ sucrose $(\mathrm{pH} 6.95)]$, containing $0.5 \%(\mathrm{wt} / \mathrm{vol}) \mathrm{BSA}$ and $0.2 \%$ Triton $\mathrm{X}-100$ (BBT) and the volumes used were $1 / 5$ reported volumes. All incubations were at $4^{\circ} \mathrm{C}$. After incubation with the primary antibody, embryos were washed twice in BBT and $3 \times$ for 30 $\mathrm{min}$ in PBT [PBS with $0.5 \%$ (wt/vol) BSA, $0.2 \%$ (vol/vol) Triton $\mathrm{X}-100]$. The secondary antibody was a horseradish peroxidaseconjugated goat anti-mouse (Biolabs) used at 1:1000, and the incubation was for 3-5 hr. After extensive washing the secondary antibody was detected using a $0.5 \mu \mathrm{g} / \mathrm{ml}$ of diaminobenzidine staining solution in $0.1 \mathrm{M}$ citric acid, $0.1 \mathrm{M} \mathrm{NH}_{4}$ acetate (pH 5.7), $0.1 \mathrm{M} \mathrm{NH}_{4} \mathrm{OH}, 0.1 \%$ (vol/vol) $p$-cresol, and $0.6 \% \mathrm{H}_{2} \mathrm{O}_{2}$. In the CNS shown in Figure 8A, the staining was enhanced using a silver enhancement kit from Amersham. Embryos $>15$ $\mathrm{hr}$ were dissected in BSS, and the nervous systems were transferred to $0.5-\mathrm{cm}$ diameter coverslips $(6-12$ per coverslip) coated with poly-L-lysine $(1 \mathrm{mg} / \mathrm{ml})$. The tissues were fixed for $10 \mathrm{~min}$ at room temperature in $4 \%$ (vol/vol) paraformaldehyde (Polysciences) in PBS containing $1 \mathrm{mM}$ EGTA, $2 \mathrm{mM} \mathrm{MgCl}$, washed three times in $\mathrm{PBS}$, and incubated at $4^{\circ} \mathrm{C}$ for two or three washes of $30 \mathrm{~min}$ each in PBT. All subsequent incubations were performed at $4^{\circ} \mathrm{C}$. The primary antibodies were diluted in PBT and incubated with the tissues overnight. After 2-3 hr of washing in PBT with several changes of solution, the tissues were incubated with fluorescein- and rhodamine-conjugated antibodies (Jackson Labs; TAGO Immunological) for 2-3 hr. After two or three brief washes, they were washed overnight in PBT. The coverslips then were rinsed briefly in PBS and placed tissue-side down in $90 \%$ glycerol, $4 \mathrm{mM} \mathrm{NaCO}_{3}(\mathrm{pH}$ 9), and 1 $\mathrm{mg} / \mathrm{ml}$ of phenyldiamine. Cultured cells were stained using a similar procedure, except the secondary incubation and ensuing washes were shorter. The immunofluorescence shown in Figure 5A was as described in Beall and Hirsh (1987), using an anti- $D d c$ polyclonal rabbit serum.

\section{Construction of mutant Ddc genes and P-element transformation}

To study the effect of mutations in element I on expression of $D d c$ in vivo, two mutations in element I were constructed using the Amersham in vitro mutagenesis kit, which is based on the method of Taylor et al. (1985). The oligonucleotides were designed to change the same bases in the native element I sequence as those altered in the $\mathrm{ml}$ and $\mathrm{m} 2$ double-stranded element I oligonucleotides (Bray et al. 1988, see materials). The mutagenesis was carried out on an M13 clone containing sequences from the $D d c$ promoter encompassing element I. Mutant M13 clones were identified by DNA sequencing. The fragments were isolated from these clones and reinserted into the $D d c$ gene so that the only changes within the gene were the 2 bp within the element I sequence. The $D d c$ gene was inserted into a P-element vector carrying the $A d h$ gene selectable marker, and this was used to generate P-element transformant strains, as described previously (Scholnick et al. 1986; Bray et al. 1988). All strains were homozygous for the inserted P element and contained only one copy of the gene. Three independent transformant strains were analyzed for each mutant gene, and all gave similar results.

\section{Acknowledgments}

We thank Tao Hsieh for the $\lambda$ gt 11 library, Liz Perkins for supplying the cultured cells, Stan Tabor for providing modified T7 DNA polymerase, Chris Brandl for the M13 helper phage, Alex Nussbaum for synthesizing the oligonucleotides, and Tim 
Hunt and Richard Jackson for supplying us with MDL. We are very grateful to Wayne Johnson for his long-suffering help in the preparation of embryo extracts, to Karen Wepsic for maintaining the population cages, and to Susan Dahlin for helping with the DNA sequencing. We also thank our colleagues for many helpful suggestions about antibody staining, antibody screening, and protein purification, in particular Welcome Bender, Barbara Dunn, Bob Kingston, Michelle Musacchio, Beth Noll, David Smouse, Stan Tabor, and Rick Wobbe. We thank Wayne Johnson, Bruce Morgan, and Jeff Simon for reading the manuscript and for many helpful discussions during the course of this work. This work was supported by National Institutes of Health grants to J.H. and B.B., an American Cancer Society grant to N.H.B. and Fotis Kafatos, and also, in part, by a grant from the Markey Charitable Trust.

\section{Note}

Sequence data described in this paper have been submitted to the EMBL/GenBank Data Libraries under accession number 15657.

\section{References}

Anderson, C.W., P.R. Baum, and R.F. Gesteland. 1973 Processing of adenovirus-2 induced proteins. J. Virol. 12: $241-$ 252.

Beall, C.J. and J. Hirsh. 1987. Regulation of the Drosophila dopa decarboxylase gene in neuronal and glial cells. Genes Dev. 1: $510-520$.

Biggin, M. and R. Tjian. 1988. Transcription factors that activate the Ultrabithorax promoter in developmentally staged extracts. Cell 53: 699-711.

Bray, S.J., W.A. Johnson, J. Hirsh, U. Heberlein, and R. Tjian. 1988. A cis-acting sequence and associated binding factor required for CNS expression of the Drosophila melanogaster dopa decarboxylase gene. EMBO /. 7: 177-188.

Brown, D.D. 1984. The role of stable complexes that repress and activate eucaryotic genes. Cell 37: 359-365.

Brown, N.H. and F.C. Kafatos. 1988. Functional cDNA libraries from Drosophila embryos. J. Mol. Biol. 203: 425-437.

Budnik, V. and K. White. 1988. Catecholamine containing neurons in Drosophila melanogaster: Distribution and development. J. Comp. Neurol. 268: 400-413.

Campos-Ortega, J.A. and V. Hartenstein. 1985. The embryonic development of Drosophila melanogaster. Springer-Verlag, Berlin.

Caudy, M., H. Vassin, M. Brand, R. Tuma, L.Y. Jan, and Y.N. Jan. 1988. daughterless, a Drosophila gene essential for both neurogenesis and sex detirmination, has sequence similarities to myc and the achaete-scute complex. Cell 55: 10611067.

Cavener, D.R. 1987. Comparison of the consensus sequence flanking translation start-sites in Drosophila and vertebrates. Nucleic Acids Res. 15: 1353-1361.

Chodosh, L.A., A.S. Baldwin, R.W. Carthew, and P.A. Sharp. 1988. Human CCAAT-binding proteins have heterologous subunits. Cell 53: 11-24.

Chou, P.Y. and G.D. Fasman. 1974. Prediction of protein conformation. Biochemistry 13: 222-245.

Crews, S.T., J.B. Thomas, and C.S.Goodman. 1988. The Drosophila single-minded gene encodes a nuclear protein with sequence similarity to the Per gene product. Cell 52: 143-151.

Davis, R.L., H. Weintraub, and A.B. Larsow. 1987. Expression of a single transfected cDNA converts fibroblasts to myoblasts. Cell 51: 987-1000.
Dequin, R., H. Saumweber, and J.W. Sadat. 1984. Proteins shifting form the cytoplasm to the nuclei during early embryogenisis of Drosophila melanogaster. Dev. Biol. 104: $37-$ 48.

Desplan, C., J. Theis, and P.H. O'Farrell. 1988. The sequence specificity of homeobox-DNA interaction. Cell 54: 10811090.

Duncan, I. 1986. Control of Bithorax complex functions by the segmentation gene fushi terazu. Cell 47: 297-309.

Fletcher, C., N. Heintz, and R.G. Roeder. 1987. Purification and characterization of OTF-1, a transcription factor regulating cell-cycle expression of a human histone $\mathrm{H} 2 \mathrm{~b}$ gene. Cell 51: 773-781.

Furst, A. and A.P. Mahowald. 1985. Differentiation of primary embryonic neuroblasts in purified neural cultures from Drosophila. Dev. Biol. 109: 184-192.

Galfre, G., S.C. Howe, C. Milstein, G.W. Butcher, and J.C. Howard. 1977. Antibodies to major histocompatability antigens produced by hybrid cell lines. Nature 266: 550-552.

Garnier, J., D.J. Osguthorpe, and B. Robson. 1978 Analysis of the accuracy and implications of simple methods for predicting the secondary structure of globular proteins. J. Mol. Biol. 120: 97-120.

Hai, T., M. Horikoshi, R.G. Roeder, and M.R. Green. 1988. Analysis of the role of the transcription factor ATF in the assembly of a functional pre-initiation complex. Cell 54: 1043-1051.

Halazonetis, T., K. Georgopoulos, M.E. Greenberg, and P. Leder. 1988. c-Jun dimerizes with itself and with c-Fos, forming complexes of different DNA binding affinities. Cell 55: 917-924.

Han, K., M.S. Levine, and J.L. Manley. 1989. Synergistic activation and repression of transcription by Drosophila homeobox proteins. Cell 56: $573-583$.

Heberlein, U. and R. Tjian. 1988. Temporal pattern of alcohol dehydrogenase gene transcription reproduced by Drosophila stage specific embryonic extracts. Nature 331: 410-415.

Heberlein, U., B. England, and R. Tjian. 1985. Characterization of Drosophila transcription factors that activate tandem promoters of the alcohol dehydrogenase gene. Cell 41: 965977.

Henikoff, S. 1984. Unidirectional digestion with exonuclease III creates targeted breakpoints for DNA sequencing. Gene 28: $351-359$.

Hollenberg, S.M., C. Weinberger, E.S. Ong, G. Cerelli, A. Oro, E.B. Thompson, M.G. Rosenfield, and R.M. Evans. 1985 Primary structure and expression of a functional human glucocorticoid receptor cDNA. Nature 318: 635-641.

Horikoshi, M., T. Hai, Y.-S. Lin, M.R. Green, and R.G. Roeder. 1988. Transcription factor ATF interacts with the TATA factor to facilitate establishment of a preinitiation complex. Cell 54: 1033-1042.

Hunyh, T.V., R.A. Young, and R.W. Davis. 1985. Constructing and screening cDNA libraries in lambda gt 10 and lambda gt11 libraries. In DNA cloning: A practical approach led. D.M. Glover), pp. 49-78. IRL Press, Oxford.

Ingham, P.W. 1988. The molecular genetics of embryonic pattern formation in Drosophila. Nature 335: 25-33.

Jackson, R.J. and T. Hunt. 1983. Preparation and use of nuclease treated rabbit reticulocyte lysate for the translation of eukaryotic messenger RNA. Methods Enzymol. 96: 50-74.

Johnson, P.F., W.H. Landschulz, B.J. Graves, and S.L. McKnight. 1987. Identification of a rat liver nuclear protein that binds to the enhancer core element of three animal viruses. Genes Dev. 1: 133-146.

Johnson, W.A., C.A. McCormick, S.J. Bray, and J. Hirsh. 1989. A 
neuron specific enhancer of the Drosophila dopa decarboxylase gene. Genes Dev. 3: 676-686.

Kadonaga, J.T. and R. Tjian. 1986. Affinity purification of sequence specific DNA binding proteins. Proc. Natl. Acad. Sci. 83: 5889-5893.

Konrad, K.D. and J.L. Marsh. 1987. Developmental expression and spatial distribution of dopa decarboxylase in Drosophila. Dev. Biol. 122: 172-185.

Levine, M. and T. Hoey. 1988. Homeobox genes as sequence specific transcription factors. Cell 55: 537-540.

Lillie, J.W. and M.R. Green. 1989. Transcription activation by the adenovirus Ela protein. Nature 338: 39-44.

Livingstone, M.S. and B.L. Tempel. 1983. Genetic dissection of monoamine neurotrasmitter synthesis in Drosophila. $\mathrm{Na}$ ture 303: 67-70.

Maniatis, T., E.F. Fritsch, and J. Sambrook. 1982. Molecular cloning: A laboratory manual. Cold Spring Harbor Laboratory, Cold Spring Harbor, New York.

Maniatis, T., S. Goodwin, and J.A. Fischer. 1987. Regulation of inducible and tissue-specific gene expression. Science 236: $1237-1245$.

Marck, C. 1988. 'DNA Strider': A 'C' program for the fast analysis of DNA and protein sequences on the Apple Macintosh family of computers. Nucleic Acids Res. 16: 1829-1836.

McGinnis, W., R.L. Garber, J. Wirz, A. Kuroiwa, and W.J. Gehring. 1984. A homologous protein coding sequence in Drosophila homeotic genes and its conservation in other metazoans. Cell 37: 403-408.

Miesfeld, R., S. Rusconi, P. Godowski, B.A. Maler, S. Okret, A.-C. Wilkstrom, J.-A. Gustaffson, and K.R. Yamamoto. 1986 Genetic complementation of a glucocorticoid receptor deficiency by expression of a cloned receptor cDNA. Cell 46: 389-399.

Miller, J., A.D. McLachlan, and A. Klug. 1985. Repetitive zinc binding domains in the protein transcription factor IIIA from Xenopus oocytes. EMBO I. 4: 1609-1614.

Morgan, B.A., W.A. Johnson, and J. Hirsch. 1986. Regulated splicing produces different forms of dopa decarboxylase in the central nervous system and hypoderm of Drosophila melanogaster. EMBO J. 5: 3335-3362.

Murre, C., P.S. McCaw, and D. Baltimore. 1989. A new DNA binding and dimerization motif in immunoglobulin enhancer binding, daughterless, myoD and myc proteins. Cell 56: $777-783$.

Nakabeppu, Y., K. Ryder, and D. Nathans. 1988. DNA-binding activities of three murine Jun proteins, stimulation by Fos. Cell 55: 907-915.

Poellinger, L. and R.G. Roeder. 1989. Octamer transcription factors 1 and 2 each bind to two different functional elements in the immunoglobulin heavy chain promoter. Mol. Cell. Biol. 9: 747-756.

Poole, S.J., L.M. Kauvar, B. Drees, and T. Kornberg. 1985. The engrailed locus of Drosophila: Structural analysis of an embryonic transcript. Cell 40: 37-43.

Ptashne, M. 1988. How eukaryotic transcriptional activators work. Nature 335: 683-689.

Regulski, M., K. Harding, R. Kostriken, F. Karch, M. Levine, and W. McGinnis. 1985. Homeo box genes of the Antennapedia and Bithorax complexes of Drosophila. Cell 43: $71-$ 80.

Rubin, G.M. and A.C. Spradling. 1982. Genetic transformation of Drosophila with transposable element vectors. Science 218: 348-353.

Santoro, C., N. Mermod, P.C. Andrews, and R. Tjian. 1988. A family of human CCAAT-box binding proteins active in transcription and DNA replication: Cloning and expression of multiple cDNAs. Nature 334: 218-224

Scheidereit, C., A Heguy, and R.G. Roeder. 1987. Identification and purification of a human lymphoid-specific octamer binding protein (OTF-2) that activates transcription of an immunoglobulin promoter in vitro. Cell 51: 783-793.

Scholnick, S., S.J. Bray, B.A. Morgan, C.A. McCormick, and J. Hirsh. 1986. CNS and hypodermal regulatory elements of the Drosophila melanogaster dopa decarboxylase gene. Science 234: 998-1002.

Scott, M.P. and S.B. Carroll. 1987. The segmentation and homeotic gene network in early Drosophila development. Cell 51: 689-698.

Soeller, W.C., S.J. Poole, and T. Kornberg. 1988. In vitro transcription of the Drosophila engrailed gene. Gene Dev. 2: $68-81$.

Staudt, L.M., R.G. Clerc, H. Singh, J.H. Lebowitz, P.A. Sharp, and D. Baltimore. 1988. Cloning of a cDNA encoding a Bcell restricted octamer binding factor. Science 241: 577580.

Struhl, G. and M. Akam. 1985. Altered distributions of Ultrabithorax transcripts in extra sex combs mutant embryos of Drosophila. EMBO J. 4: 3259-3264.

Tabor, S. and C.C. Richardson. 1987. DNA sequence analysis with modified bacteriophage T7 DNA polymerase. Proc. Natl. Acad. Sci. 84: 4767-4771.

Taggart, R.T. and I.M. Samloff. 1982. Stable antibody producing murine hybridomas. Science 219: 1228-1230.

Taylor, J.W., J. Otto, and F. Eckstein. 1985. The rapid generation of oligonucleotide-directed mutations using phosphorothioate modified DNA. Nucleic Acids Res. 13: 8765-8785.

Towbin, H., T. Staehlin, and J. Gordon. 1979. Electrophoretic transfer of proteins from polyacrylamide gels to nitrocellulose sheets: Procedures and some applications. Proc. Natl. Acad. Sci. 76: 4350-4354.

Treizenberg, S.J., K.L. Lamarco, and S.L. McKnight. 1988. Evidence of DNA: Protein interactions that mediate HSV-1 immediate early gene expression. Genes Dev. 2: 730-742.

Tsai, S.Y., I. Sagami, M.-J. Tsai, and B.W. O'Malley. 1987. Interactions between a DNA binding transcription factor (COUP) and a non-DNA-binding factor (S300-11). Cell 50: 701-709.

Vales, A.M. and K. White. 1988. Serotonin-containing neurons in Drosophila melanogaster, development and distribution. I. Comp. Neurol. 268: 414-428.

Weintraub, H. 1985. Assembly and propagation of repressed and derepressed chromosomal states. Cell 42: 705-711.

Wharton, K.A., K.M. Johansen, T. Yu, and S. Atavanis-Tsakonas. 1985. Nucleotide sequence from the neurogenic locus Notch implies a gene product that shares homology with proteins containing EGF-like repeats. Cell 43: 567581.

Wright, T.R.F., G.C. Bewley, and A.F. Sherald. 1976. The genetics of dopa decarboxylase in Drosophila melanogaster II. Isolation and characterization of dopa decarboxylase deficient mutants and their relationship to the alpha-methyldopa hypersensitive mutants. Genetics 84: 287-310.

Wright, W.E., D.A. Sassoon, and V.K. Lin. 1989. Myogenein, a factor regulating myogenesis has a domain homologous to myoD. Cell 56: 607-617. 


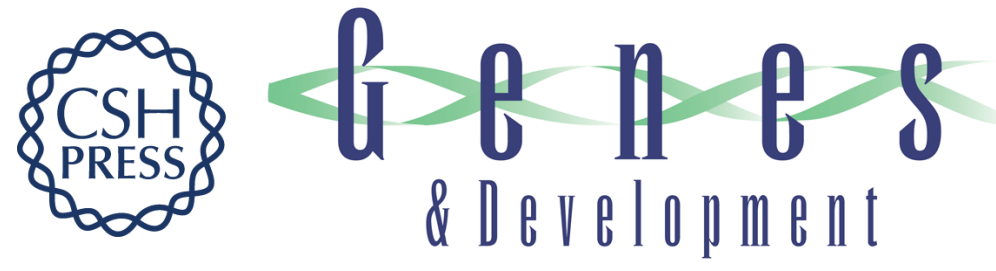

\section{Embryonic expression pattern of a family of Drosophila proteins that interact with a central nervous system regulatory element.}

S J Bray, B Burke, N H Brown, et al.

Genes Dev. 1989, 3:

Access the most recent version at doi:10.1101/gad.3.8.1130

References This article cites 68 articles, 15 of which can be accessed free at:

http://genesdev.cshlp.org/content/3/8/1130.full.html\#ref-list-1

License

Email Alerting

Service

Receive free email alerts when new articles cite this article - sign up in the box at the top right corner of the article or click here.

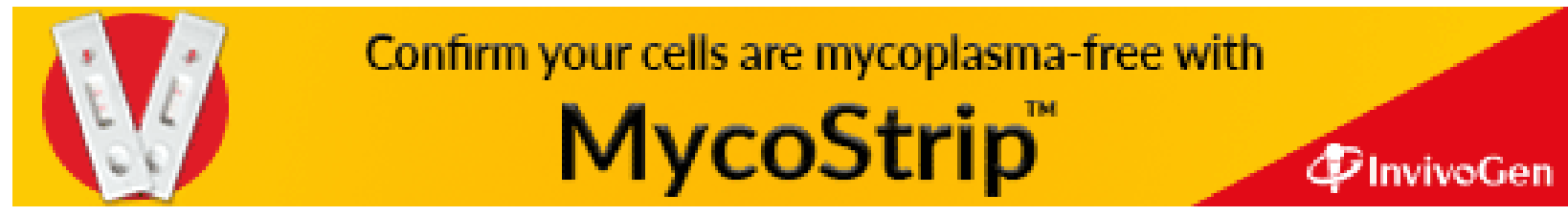

